\title{
Functional trinity of public finance in an emerging economy
}

\author{
Emilian Dobrescu* ${ }^{*}$
}

\section{${ }^{*}$ Correspondence:}

emdobrescu1@gmail.com Center for Macroeconomic Modelling, National Institute for Economic Research, Romanian Academy, 13, Calea 13 Septembrie, 050711 Bucharest, Romania

\begin{abstract}
Two challenges in the literature have inspired this paper. First, the highly contradictory puzzle of debates on the "public budget-economic growth" correlation, explainable in great measure by the inadequacy of involved modeling tools (assumptions and specifications) with studied samples. Regarding this issue, the paper proposes three temporal scales of analysis: (1) the global historical trajectory of the modern society, concerning which the Wagner-Kaldor theorem has a leading explicative position; (2) the given structural state-society relationship, for which Barro-Armey-Rahn-Scully (BARS), Laffer in narrower sense (LINS), and the public budget balance restriction (BBR) curves are more suited; and (3) the short-medium horizon, where the Keynesian and post-Keynesian framework remains relevant. Another starting point of this paper refers to the second scale. While the BARS and LINS curves were extendedly examined, the BBR one benefited of attention only during the last period in the context of the sovereign debt crisis. Besides, all these functions were studied separately. Since in the real economy they interact continuously, we integrate BARS, LINS, and BBR curves into a unitary model with a "compatibility restriction" as technical solution. Data for an emergent medium-sized EU country (Romanian case study) illustrate this approach.
\end{abstract}

Keywords: Public budget, BARS, LINS, BBR, Collinearity, Compatibility restriction, Model simulations

\section{Background}

The literature on government finances has gravitated toward the following issues: (1) the impact of public budget expenditures on the degree of society's general development, especially the productive outcome of the economy; (2) the collected taxes as the most important component of the public budget's income; and (3) the capacity of government to obtain credit from financial markets as a complementary resource for its own expenses.

The corresponding literature is characterized by strikingly contradictory viewpoints.

Some authors have commented that government expenditure is almost neutrally related to aggregate output: besides the famous Harberger $(1964,2003)$ conjecture (Engen and Skinner 1996; Mark et al. 1997; Mendoza et al. 1997; Wasylenko 1997; Hines 2002; Xing 2011). Some studies have considered this impact negative: Mark et al. (1997), Beach (1998), Poulson and Kaplan (2008), McBride (2012), Pettinger (2017). The opinions positing the positive influence of government spending

(c) The Author(s) 2018. This article is distributed under the terms of the Creative Commons Attribution 4.0 International License (http://creativecommons.org/licenses/by/4.0/), which permits unrestricted use, distribution, and reproduction in any medium, provided you give appropriate credit to the original author(s) and the source, provide a link to the Creative Commons license, and indicate if changes were made. 
on economic growth predominate, and such a role is attributed to the so-called productive items of the public budget (Kneller et al. 1999); notably, Asimakopoulos et al. (2016) included them into their macroeconomic production function.

Divergent opinions have also been formulated concerning public budget taxes. Mertens and Ravn (2013) identified immediate effects on output induced by changes in average tax rates. Engen and Skinner (1996) posited, "the tax level is likely to exert a modest, but cumulatively important, influence on long-term growth rates. (p. 36)." Structurally, many studies have outlined the unequal consequences of various taxes on output. Therefore, although taxation of income and profit, payroll and labor, property, and social security contributions would cause distortions, no such effect was identified for other taxes (Kneller et al. 1999). Concerning capital taxation, the theoretical modeling indicated a complicated sinusoidal evolution, from level zero (Judd 1985; Chamley 1986) to relatively high rates (Piketty and Saez 2013). Lee and Gordon (2005) found that the corporate tax rate is negatively correlated with economic growth, but other tax variables are not significantly associated.

The variegated picture of the research conclusions on the "public budget-economic growth" tandem was described in overviews, such as Huang (2006), Kenny and Winer (2006), Afonso et al. (2008), Myles (2009), Magazzino and Forte (2010), MartinezVazquez et al. (2011), Magazzino (2012), McBride (2012), Nygård and Revesz (2015), Afonso and Alves (2016), Dobrescu (2016a), Winer (2016), Churchill et al. (2017), Fisman et al. (2017), and Gomez-Puig and Sosvilla-Rivero (2017).

How can such interpretative diversity be explained? The epistemological premises of various studies and the real specificities of studied experiences cannot be ignored. Working on this paper, we concluded that only these circumstances are not sufficient.

A significant cognitive impact arises from underestimating the temporal scale to which the examined problems refer. Or concerning government finance, the delimitation of three perspectives seems essential.

The first one considers the global historical trajectory of modern society, for example, the Wagnerian hypothesis (Wagner 1883). With roots in classical economics, the anticipation that economic development will be accompanied by an increasing share of government expenditure in national income has been confirmed by authorized statistical series. Inherent parallel growth of taxation-admitted still by Wagner-was comprehensively discussed by Kaldor (1962, 1963a, b). The syntagm "Wagner-Kaldor law" is justified.

Another perspective concerns the limited temporal segment, provisionally named a "given structural state-society relationship", as a distinct component of the larger notions, such as human social environment (Barnett and Casper 2001), social capital (Field 2008), social structure in a network-based perspective (Mukherjee 2007), or a given historical context (Dobrescu 2016a). The binomial state-society is dynamic, its forms and ampleness modifying along global history and within the same social system. Such changes occur periodically, and existing intervals with sufficiently stable features include: the dominant behaviors of people as taxpayers and beneficiaries of public spending. In this paper, we shall refer exactly to these intervals. 
Finally, note the short-medium horizon, and the problems of such a time span being prioritary for macroeconomic policies. Keynesian and post-Keynesian models remain relevant for such intervals.

In our opinion, if empirical research does not account for these temporal scales, its consistency is inevitably affected.

The trap of applying or checking the theorems on improper samples of observations was unavoidable. Among such temptations, especially risky would be to relate the Wagner-Kaldor law to limited historical information or, by contrast, to expostulate the Keynesian schemes to long and very long series.

Similar problems occur when PANEL analyses involve data belonging to economies in different development stages. The assertion-sometimes deduced from such studiesthat data corroborate the Wagner-Kaldor law for low-income countries while rejecting it in the case of rich ones, overlooks that this law envisages the global historical trajectory of society and not its various segments.

A possible disregard of the temporal scale of analysis can also be observed in model specification. The econometrics of the Wagner-Kaldor law is again edifying and intended for a relationship on very long horizon between output and ratio of government spending to gross domestic product (GDP). In its formalization, the main difficulty stems from the non-unitary evolution of the involved variables. Although the potential output registered an obvious increasing trend, the share of government expenditure in GDP cannot extend unlimitedly. At superior development stages, despite the increasing per-capita income, the social acceptability of taxation decelerates, tending toward an asymptotical level. (Normally, it is situated under unity, which is its maximum potential limit.) This trend seems to be linked to the extending capacity of the private sector to provide some public goods and services, and enforcing democratic control on government decisions. Consequently, in modeling the size of the government in relation to economic growth long term, the threshold regression methods are more suitable (Christie 2011) as well as nonlinear functions (Kuckuck 2012; Hajamini and Falahi 2014; Aghion et al. 2016), including the logistic one (Florio and Colautti 2002; Magableh 2006). In this context, notably, is the conclusion drawn by Fölster and Henrekson (2001): The relationship between government expenditure and growth is negative in rich countries.

This research focused on government finance for a given structural state-society relationship in the frameworks of the second aforementioned delimited temporal scale. Under such conditions, the relative stability of three dominant social behaviors is assumed, namely:

(a) State intervention propensity, especially concerning the government spending,

(b) Tax acceptability, and

(c) Risk aversion to public indebtedness.

All these conditions are sociological reactive processes [as characterized in Mahoney (2000)]. Any change in the institutional framework of public budget expenditures, taxation, or public debt evolution is followed-as a rule-by counter reactions (i.e., upback or pushback) on the side of domestic economic agents, foreign markets, civic organizations, mass media, political formations, and public opinion in general. 
The tendency toward equilibrium of society generates some steady-state levels of leading indicators, defining quantitatively the aforementioned behaviors: the share of public budget expenditures in GDP, degree of tax acceptability, and public debt size. Obviously, these levels are specific for each given structural state-society relationship.

Admittedly, the dynamics of actual processes around the steady-state levels is submitted concomitantly-similarly to other economic dependences-to the scale efficiency and diminishing marginal returns' theorems. The advantages of scale efficiency appear more intensive when the involved indicators are situated at the left side of the steady-state levels (low government spending, taxation, and public debt), whereas the diminishing marginal returns become prevalent at the right side of these points (higher government spending, taxation, and public debt). Sociologically, the first slope could be considered a self-reinforcing sequence, and the second a sui-generis self-undermining one. The U-shaped form of the main relationships of government finance therefore approximates the real socioeconomic life. A deeper discussion of these problems exceeds the intended framework of this paper and was evoked only as assumptions of the subsequent analyses.

In the empirical research, a database was used for an emergent medium-sized EU economy (Romania, as a case study), with series for two and half decades, namely, 1990-2016. Despite the transformations induced by the transitional processes, after the first package of reforms in 1990s, the structural state-society relationship became, to a great measure, congruent with the functional market economy's requirements. In principle, therefore, such a database can be admitted as relevant to the paper's goal. The specificities of an emergent economy could be a profitable challenge to a scientific plan because they extend the cognitive area of an issue developed, until now, preponderantly on advanced occidental countries.

More concretely, the involved in-paper indicators refer to the general consolidated budget (GCB), which aggregates data for the central and local public budgets, the social insurance budget, and other similar funds. The classification of GCB revenues and expenditures adopted by the 2012 version of the Romanian macromodel (Dobrescu 2013a, b, 2015b) has been used. This classification is presented in Additional file 1: Appendix A, and the corresponding statistical series are detailed in Additional file 2: Appendix B.

This paper continues with a description of the main functional relationships characterizing government finances, including the collinearity problem associated with the U-shaped form of these relationships. More specifically, the Barro-ArmeyRahn-Scully (BARS) curve, the Laffer in narrower sense (LINS) curve, the specifications for non-fiscal public budget revenues (NFBR), and the public budget balance restriction (BBR) are examined separately (like in the literature) and as an integrated model. With such an aim, we introduced a compatibility restriction derived from the unitary framework, within which these functions intimately interact under a given structural state-society relationship.

Several conclusions and further possible research opportunities complete the paper. 


\section{Methods}

\subsection{Macromodel specification}

The dynamics of social welfare depend on the GDP. A part of it $\left(W_{b}\right)$ depends on public budget expenditures in a double sense: (1) directly-the budget sector supply of goods and services usually included in the GDP nomenclature, and (2) indirectly-the impact of government spending (for example, education, infrastructure, favorable business environment) on the performance of the non-budgetary sector (total factor productivity of economy). What are the costs pertaining to $\left(W_{b}\right)$ ? The most representative are the taxes supported by households, firms, and institutions. The government finance therefore revolves around the following relationships:

$$
I G B=f(c b e, I O T)
$$

$I G B$, economic growth, is measured by an index of the real output (gross or net domestic product) as volume or per capita. cbe, ratio to GDP of the public budget expenditure. $I O T$, contribution to IGB of non-budget factors.

$$
B E=B R-B B=T A X T+N F B R-B B
$$

$B E$, volume of the public budget expenditures. $B R$, volume of the public budget revenues. $B B$, public budget balance. TAXT, total of the collected taxes. NFBR, non-fiscal public budget revenues.

$$
T A X T=T A X T L * \text { letg }
$$

TAXTL, total of the legal taxation. letg, legal-effective taxation gap as a proportion in which the legal taxes are on average actually paid.

Translated into ratios to GDP (prefix c), identities (2) and (3) transform into the equality:

$$
c b e=a \operatorname{tax} * \operatorname{letg}+c n f b r-c b b
$$

atax, average legal taxation.

Obviously, the specification of an applicative model must consider the peculiarities of the simulated economy.

\subsection{BARS curve}

The interpretation of the impact of public budget expenditures on economic growth as an inverted U-shaped dependence was consecrated as the BARS curve-an acronym of its founders' names: Scully (1989, 1995, 1998), Barro (1990, 1991), Armey (1995), and Rahn and Fox (1996). Subsequent contributions to this topic belong to Tanzi and Schuknecht (1996), Chao and Grubel (1998), Gwartney et al. (1998), Tanzi and Schuknecht (2000), Tanzi (2005), Bania et al. (2007), Afonso et al. (2008), Altunc and Aydin (2013), Facchini and Melki (2013), and Di Liddo et al. (2015). By applying a nonlinear panel GMM approach on the database of 129 countries (World Bank statistics), Asimakopoulos and Karavias (2016) revealed a consistent nonlinear relationship between 
government spending and economic growth. Short bibliographical overviews are presented in Magazzino and Forte (2010), Dobrescu (2015a).

In the simplest functional determination, the combination of scale efficiency and diminishing marginal returns, under the condition that $I G B$ depends exclusively on $I O T$ for $c b e=0$, can be formalized as:

$$
I G B=\beta_{1} * c b e+\beta_{2} * c b e^{2}+\beta_{3} * I O T
$$

The BARS curve assumes $\beta_{1}>0$ and $\beta_{2}<0$, according to which the ratio $\beta_{1} /\left(-2 * \beta_{2}\right)$ approximates the optimal level of cbe. In our econometric application, IGB is represented by the annual index of the GDP at constant prices (IGDPc). The rest of the specification uses the proposals from Dobrescu (2015a, 2016b) with several modifications: (1) cbe is included as a lagged value; (2) a lagged value is used again for the capital formation influence; and (3) the time variable appears as a smooth increasing trend $t /(t+1)$, that is, its estimator is transforming asymptotically into an intercept. Consequently, the following specification of the BARS curve is adopted:

$$
I G D P c=c(1) * c b e(-1)+c(2) * c b e(-1)^{2}+c(3) * \operatorname{IGFCF} c(-1)+c(4) * t /(t+1)
$$

where $I G F C F c$ is the annual index of the gross fixed capital formation at constant prices.

\subsection{LINS curve}

The interpretation of taxation as costs of $W_{b}$ outlines the significance of the "Wicksellian connection" (Winer 2016). When the taxpayers perceive that legal taxes surpass the quality and quantity of the supplied public goods and services, their enforcing opposition to such a system is expectable.

The modern standard model was initiated by Allingham and Sandmo (1972), who attempted an early conceptualization of this mechanism by defining an analytical tool based on contributions from Becker, Tulkens, Jacquemin, Arrow, Mossin, Von Neumann-Morgenstern (Allingham and Sandmo 1972). Shortly after this notable contribution, Yitzhaki (1974) added to its specification the penalty for discovered evasion. As a result, the complete model is sometimes called "Allingham-Sandmo-Yitzhaki" (Slemrod and Yitzhaki 2002). Among the alternate approaches, the prospect theory (Kahneman and Tversky 1979) and experimental applications represented also important contributions. The topic has been debated in numerous studies, for example: Becsi (2000), Kirchler and Braithwaite (2007), Bruhin et al. (2010), Iyer et al. (2010), Kleven et al. (2010), Alm (2012), Laffer (2012), Piolatto and Rablen (2013), Holter et al. (2014), Myles (2014a, b), Isakov and Pekarski (2015), and Pappadà and Zylberberg (2016). Also notable is the increasing interest in the study of this topic on transitional economies: Johnson et al. (1997) (in connection with unofficial economy) (Papava 2002; Walewski 2009; Dobrescu 2016b).

The inverted U-shaped curve of collected taxes as a function of compulsory rates was associated in the beginning of the 1970s with Arthur Laffer, although such dependencies - at least intuitively_had been previously identified (see Laffer 2004; Bartlett 2012a, b, c). Following Feldstein's papers (1995a, b, 1999) on the reaction of companies and households to taxation, the concepts of "tax gap" (Andreoni et al. 
1998; James and Alley 2002), "tax compliance gaps" (Gemmell and Hasseldine 2013), and "the legal-effective tax gap (letg)" (Dobrescu 2016b) were formulated. This formalization has been referred to as the LINS curve.

In short, the LINS curve reflects the dynamics of legt because of the interaction between the following:

(a) "tax acceptability" which cumulates the "tax morale" (Torgler and Schaltegger 2006; Myles 2014a) as a voluntary compliance and the government capacity to impose the fiscal rules or "fiscal coercion" (Akhand and Hubbard 2016), "economic deterrence" (Devos 2007), and

(b) "tax aversion" (Soldatos 2015) or "tax repulsiveness" (Dobrescu 2016b). Schematically, this interaction can be described as follows. Voluntary compliance accommodates with increasing taxes as long as the growth of cbe based on them is perceived by public opinion as providing adequate benefits for society. At higher levels of taxation, however, such a perception weakens, or disappears, transforming into an amplified repulsiveness (which stems from the natural propensity of economic agents to dispose autonomously of their own income as much as possible). Tax repulsiveness induces an accentuated opposition against related regulations, boosting legal, and illegal tax evasion and other civil disobediences. The capacity of the government to impose the rules has, of course, unsurpassable socioeconomic and institutional limitations.

As a function of the global taxation rate (atax), the dynamics of letg also conform to an inverted U-shaped curve. Easily interpretable and computationally convenient, the parabola with maximum was again preferred:

$$
\text { letg }=\lambda_{1} * \operatorname{atax}+\lambda_{2} * \operatorname{atax}^{2}+\lambda_{3} * L O T
$$

where $L O T$ is other factors influencing the legal-effective tax gap.

The LINS curve involves $\lambda_{1}>0$ and $\lambda_{2}<0$. The ratio $\lambda_{1} /\left(-2 * \lambda_{2}\right)$ can therefore be observed as an optimal level of the atax, under a given structural state-society relationship. Similar to the BARS curve, in the case of $L O T$, the econometric specifications are accommodated to the available statistics and features of the economy in cause.

In our application, among the explicative variables-aside from atax at a previous interval-a time variable was introduced to capture the temporary impact of transitional processes. As the new market mechanisms consolidate, this impact weakens gradually. In this manner, the following formula was retained:

$$
\operatorname{letg}=c(5) * \operatorname{atax}(-1)+c(6) * \operatorname{atax}(-1)^{2}+c(7) / t .
$$

\subsection{BBR curve}

As an outturn account, budget balance (the difference between public budget expenditures and public budget revenues) can be positive (a surplus), null, or negative (a deficit). For both nonzero $c b b$, constraints exist. The positive one is capped by the society's availability to finance other countries instead of using their own budget 
resources for internal needs. The negative one encounters the sensitivity of the potential lenders concerning the dimension of public debt $(P D)$ compared with national output $(p d g=P D / G D P)$. The existence of a ceiling for $c b b$ (noted $c b b r$ ) seems therefore admissible.

In the real economy, the effective $c b b$ deviates from this benchmark. Such a difference $(c b b o)$ :

$$
c b b=c b b r+c b b o
$$

is induced by two groups of factors. First, special circumstances can influence, in a stable way (for a longer or shorter period), the public budget balance. The structural funds allocated by the EU are an example, and this time, very favorable for the countries in cause. Nevertheless, a possible sovereign debt crisis generates a converse situation. In addition to such circumstances, the oscillations around the steady-state levels intrinsically characterize the socioeconomic processes.

Opinions diverge regarding the macroeconomic implications of the $p d g$ level. High public debt was frequently accepted as having, in general, a negative impact on economic growth (Bose et al. 2003; Greiner 2014; Pescatori et al. 2014; Stone 2014; Trecroci and Salotti 2014). There are also more-nuanced opinions, in the sense that an increasing relative public debt could be positive in the short run but has a negative effect in the long run (Elmendorf and Mankiw 2000; Gomez-Puig and Sosvilla-Rivero 2017). Some studies have revealed an ambiguous relationship between public debt and growth and, in any case, a high heterogeneity of this correlation across countries and time periods (Kumar and Woo 2010; DeLong and Summers 2012; Lof and Malinen 2013; Panizza and Presbitero 2013).

Most opinions, however, have favored the existence of an extremal point (even if it does not always allow clear definition), beyond which amplifying public debt restrains the economic development of a given country (Pattillo et al. 2002; Reinhart and Rogoff 2010; Checherita-Westphal et al. 2012; Panizza and Presbitero 2012; Reinhart et al. 2012; Égert 2015; Ahlborn and Schweickert 2016). We assume this hypothesis, accepting a positive effect of increasing public debt up to a certain ceiling, beyond which its impact becomes converse. In correlation with this factor, budget deficits can initially expand, but the opposite effect is subsequently generated. In other words, the aforementioned combination of scale efficiency and decreasing marginal returns may be interpreted as a reciprocal function, in comparison with the BARS and LINS curves. Again, in a simple formalization, this relationship will be:

$$
c b b r=k 1 * p d g+k 2 * p d g^{2}+k 3 * O B B
$$

where $O B B$ is other factors influencing the budget deficit, within the borders of the public debt restriction.

Since budget deficits are recorded with a negative algebraic sign, their dependence on public debt displays a U-shaped curve. In the case of potential surpluses, when the balance becomes positive, the resulting curve is an inverted $U$ shape.

Considering the duration of loan negotiations, in our application, the $c b b r$ function includes $p d g$ as a lagged variable. Regarding the $O B B$ factors, the statistical analysis revealed a cyclical influence of a four-year length, which coincides with the frequency 
of the Parliamentary elections. The link between public budget deficits and alternation of political power has been revealed in many other countries (Brender and Drazen 2004; Mink and de Haan 2006; Shi and Svensson 2006; Klomp and De Haan 2013; Haan 2014). Therefore:

$$
c b b=c(8) * p d g(-1)+c(9) * p d g(-1)^{2}+c(10) * \sin t 4
$$

where $\sin t 4=\sin \left(2^{*} \pi^{*} t / 4\right) / t$.

Obviously, such a statistical approximation must be made with caution because the maximum bearable level of public debt is conditioned by numerous internal and external circumstances-from natural and accumulated endowment, active population, performance of the institutional framework, and general development degree of the given economy up to the current and predictable regional or global geostrategic context. Additionally, independent from the econometric estimations, such ceiling parameters can be officially adopted, either at the national (United States Public Debt Act) or international (the Maastricht Treaty criteria in European Union) levels.

If extra-statistical reasons or unpredictable factors induce lesser or greater levels of $c b b$, in comparison with the estimated $c b b r$, the difference ( $c b b o)$ must be established exogenously.

\subsection{Additional relationships}

To coagulate an integrated public budget model, the aforementioned functional trinity, namely, the BARS, LINS, BBR curves, must be supplemented with some auxiliary relationships.

BARS function (5) contains the factor $\operatorname{IGFCFC}(-1)$. For a static simulation, this indicator could be considered as a given, but for a dynamic one such an assumption fails; therefore, it must be transformed into an endogenous variable.

The gross fixed capital formation $(G F C F)$ and $G D P$, both at current prices, are recalculated at constant prices $(G F C F C$ and $G D P c)$ by using the corresponding deflators (PK and $P G D P$ ). In this manner, the ratio of $G F C F C$ to $G D P c$ will be as follows:

$$
r g f c f c=G F C F /(G D P * c k)
$$

where $c k=P K / P G D P$.

After some elementary algebraic operations, the formula of interest is the following:

$$
I G F C F c=r g f c f c * I G D P c /(r g f c f c(-1) * c k(-1))
$$

The new parameters, $r g f c f c$ and $c k$, are determined econometrically. The first one accounts for the inertial characteristic of the investment process and expectations regarding taxation:

$$
r g f c f c=c(11)+c(12) * r g f c f c(-1)+c(13) * \operatorname{atax}(1)
$$

Concerning the deviation of the GFCF deflator to the GDP one (which per se is small enough), the lagged value and a cyclical influence were retained,

$$
c k=c(14)+c(15) * c k(-1)+c(16) * \sin t 4
$$


A similar solution was adopted for the coefficient of the non-fiscal budget revenues $(c n f b r=N F B R / G D P)$, with the difference being that the cycle length covers two successive Parliamentary elections this time:

$$
\begin{aligned}
& c n f b r=c n f b r(-1)+d(c n f b r) \\
& d(c n f b r)=c(17)+c(18) * c n f b r(-1)+c(19) * \sin t 8
\end{aligned}
$$

where $\sin t 8=\sin \left(2^{*} \pi^{*} t / 8\right) / t$.

\subsection{Collinearity problem}

The usual specifications of the BARS, LINS, and BBR curves involve a high correlation between series $c b e$, atax, $p d g$, and their quadratic forms. In our application, the Pearson-Galtung coefficients for the corresponding pairs are as follows: $0.99913 c b e-c b e^{2}$, $0.99843 a t a x-a t a x^{2}$, and $0.98579 p d g-p d g^{2}$. As expected, in regressions, the estimators register a great variance inflation factor.

An extended literature has gravitated toward this problem. (Some synthetic overviews can be found in Wold et al. 1984; Belsley 1991; Dalal and Zickar 2012.) Among the sources of collinearity, the polynomial specification was especially examined (Bradley and Srivastava 1977; Shacham and Brauner 1997; Yu and Tempe 2000; Seber and Lee 2003; Piegorsch 2015; Helwig 2017).

Several methods have been advanced to identify and quantify the size (hence, the gravity) of such a phenomenon (Farrar and Glauber 1967; Kumar 1975; O'Hagan and McCabe 1975; Wichers 1975; Belsley 1991; Goldberger 1991; Gujarati 2003; Seber and Lee 2003; Paul 2006; O’Brien 2007; Robinson and Schumacker 2009; Wooldridge 2009; Baguley 2012; Dallal 2012b; Greene 2012; Dormann et al. 2013; Uriel 2013; Piegorsch 2015; Hansen 2018). The most used is probably the variance inflation factor (VIF).

Many studies have discussed the possible remedies for collinearity, preponderantly referring to the individual relationships.

"Do nothing" is one of them (Gujarati 2003; Allison 2012). A possible motivation could be that, as a rule, the collinearity does not alter the cumulated effect of the respective explanatory variables, or in a lot of applications, the principal goal is to obtain a computational instrument for extra-sample estimations. Subtextually a constancy of the collinearity structure is presumed, which is uncertain or admissible only in the proximity of the used sample; otherwise, evidently, "do nothing" becomes - at least-questionable.

A re-specification of the model (Farrar and Glauber 1967; Yu and Tempe 2000; Gujarati 2003; Paul 2006; O'Brien 2007; Baguley 2012; Greene 2012; Uriel 2013) is another advocated approach. If the objective and relevance of the research in cause allow such an operation, it would be categorically preferable. The simplest method is the amputation of redundant variables. However, to cut an essential variable only for the sake of collinearity could be too high a cognitive cost; this is the reason why modeling is compromised.

Due to the presumption that the collinearity is mainly a data problem, some remedies concern the used information. For example, the following are recommended:

- increase the sample when possible (Farrar and Glauber 1967; Yu and Tempe 2000; Gujarati 2003; Paul 2006; Baguley 2012; Greene 2012; Uriel 2013); 
- data-transforming procedures (Bradley and Srivastava 1977; Mandel 1985; Gujarati 2003; Seber and Lee 2003; Baguley 2012; Dallal 2012a; Uriel 2013; Piegorsch 2015; Iacobucci et al. 2016) as mean centering, standardized data, and replacement by ratios or logarithms;

- subset selection (Hastie et al. 2008) to eliminate the data that are "impeachable" for collinearity.

The available a priori information usable for introducing constraints in the estimation procedure should not be neglected (Farrar and Glauber 1967; Gujarati 2003; Uriel 2013). The sources of such a possibility are multiple: the theoretical foundations of the model, the cross-sectional sample, or the data provided by other empirical studies.

For example, in the case of the BARS, LINS, and BBR curves, the sociological surveys may be a valuable support. Based on such information, the optimal levels ocbe, oatax, and opdg could be approximated from relationships (5), (7), and (10). Consequently, the ratios between the estimators of the collinear variables (prefix $\rho$ ) would be easily deducible:

$$
\begin{aligned}
& \rho B A R S=c(1) / c(2)=-2 * \text { ocbe } \\
& \rho L I N S=c(5) / c(6)=-2 * \text { oatax } \\
& \rho B B R=c(8) / c(9)=-2 * \text { opdg }
\end{aligned}
$$

In this manner, the collinearity problem disappears.

A consistent package of technical solutions was developed that aimed to eliminate or attenuate the implications of collinearity. A brief and illustrative enumeration is available: the principal components analysis (Gujarati 2003; Paul 2006; Hastie et al. 2008; Chen 2009, 2012; Dallal 2012b; Greene 2012; Piegorsch 2015), partial least squares (Yu and Tempe 2000; Chen 2009, 2012), staged regression (Chen 2009, 2012), and the robust conjecture approach (Chen 2012).

In the literature, the utilization of the ridge regression has been extended (Hoerl and Kennard 1970; Mandel 1985; Gujarati 2003; Seber and Lee 2003; Paul 2006; O’Brien 2007; Hastie et al. 2008; Chen 2009, 2012; Younker 2012; Piegorsch 2015; van Wieringen 2018) and that of other similar constraints, such as the least absolute shrinkage and selection operator-Lasso (Seber and Lee 2003; Hastie et al. 2008; Younker 2012; Piegorsch 2015), and the least angle regression-LARS (Younker 2012). To interpret these procedures as a purely numerical operation with doubtful semantics would be tempting, but superficial. More reasonable, in our opinion, would be to admit that changes made in the covariance matrix correspond to some implicit sample modifications. A re-examination from such a viewpoint of the ridge-type techniques would be a promising scientific challenge.

In the case of the present application, we tried to avoid the so-called do nothing approach by trying to use the recommended methods for compressing VIF. Since the principal objective of analysis was a numerical approximation of the parameters defining U-shaped slopes (BARS, LINS, and BBR curves), the elimination of one from 
collinear explicative variables failed ab initio. Significance for our research a priori information was not found. The ridge regression proved irrelevant.

The data-transforming procedure has been applied in the mean-centering form. Table 1 compares the estimations obtained using the original and mean-centered series. In all three relationships, the VIF decreases but with unacceptable consequences.

Thus, in the case of the BARS and LINS curves, the algebraic signs became contrary to those theoretically expected (and attested by original series). An essential coefficient of a BBR curve is insignificant. Therefore, the mean-centering procedure did not work.

In conclusion, the trials to ameliorate VIF by usual collinearity remedies failed, and this phenomenon raises an important question: Maybe the polynomial form of the explicative variables is congenitally improper for our application. Such a specification can-of course-be replaced, but it would be undesirable because the parabola has indisputable interpretative pluses.

Before deciding what solution would be preferable, a random-number exercise was processed, and its starting point was a largely accepted statement: The most unpleasant effect of collinearity is the estimates' volatility, associated with changes in the used sample. For a simplified expression of the BARS, LINS, and BBR curves (only $x$ and $x^{2}$ without other factors), 100 samples were constituted, each of them containing $26 x-y$ pairs of randomly chosen primary series. Because of the inherent repetitions, these samples differ between them in ordering of pairs and the terms themselves (in diverse proportions); in this manner, it was created the first set of samples. The second was obtained by eliminating the last row of pairs from set 1 ; proceeding similarly, the third set was composed with 24 pairs, the fourth set with 23 pairs, and the fifth set with 22 pairs. Consequently, the BARS, LINS, and BBR curves were determined for 500 samples. On this basis we examined:

Table 1 Estimations by a mean-centering procedure compared with the original data

\begin{tabular}{|c|c|c|c|c|c|c|c|c|}
\hline Estimator & Coeff. & SE & Prob. & Uncentr.VIF. & Coeff. & SE & Prob. & Uncentr.VIF \\
\hline Original data & & & & & Mean-cent. data & & & \\
\hline \multicolumn{9}{|l|}{ BARS } \\
\hline$c(500)$ & & & & & 0.59269 & 0.13466 & $2.00 E-04$ & NA \\
\hline$c(1)$ & 3.89484 & 1.08741 & 0.0017 & 1831.267 & -0.982 & 0.51415 & 0.07 & 1.88359 \\
\hline$c(2)$ & -6.1117 & 2.05932 & 0.0071 & 822.2038 & 19.3968 & 13.5041 & 0.166 & 1.66784 \\
\hline$c(3)$ & 0.13639 & 0.06035 & 0.0341 & 52.11735 & 0.11111 & 0.05853 & 0.072 & 1.20984 \\
\hline$c(4)$ & 0.29429 & 0.14137 & 0.0492 & 208.0542 & 0.33406 & 0.13519 & 0.022 & 1.32065 \\
\hline \multicolumn{9}{|l|}{ LINS } \\
\hline$c(501)$ & & & & & 0.60997 & 0.01506 & 0 & NA \\
\hline$c(5)$ & 3.11878 & 0.25275 & 0 & 144.9425 & -0.5907 & 0.23838 & 0.022 & 2.26558 \\
\hline$c(6)$ & -3.8849 & 0.62866 & 0 & 180.2087 & 9.84449 & 3.27783 & 0.007 & 1.54104 \\
\hline$c(7)$ & -0.3209 & 0.19454 & 0.1132 & 6.385676 & -0.4657 & 0.15021 & 0.005 & 2.43814 \\
\hline \multicolumn{9}{|l|}{$B B R$} \\
\hline$c(502)$ & & & & & -0.0323 & 0.00432 & 0 & $\mathrm{NA}$ \\
\hline$c(8)$ & -0.2283 & 0.05239 & 0.0002 & 18.80119 & -0.0004 & 0.03858 & 0.993 & 1.13524 \\
\hline$c(9)$ & 0.41726 & 0.15136 & 0.0112 & 18.82267 & 0.59931 & 0.25075 & 0.026 & 1.16495 \\
\hline$c(10)$ & 0.00437 & 0.00508 & 0.3983 & 1.005027 & 0.00512 & 0.00516 & 0.332 & 1.02795 \\
\hline
\end{tabular}




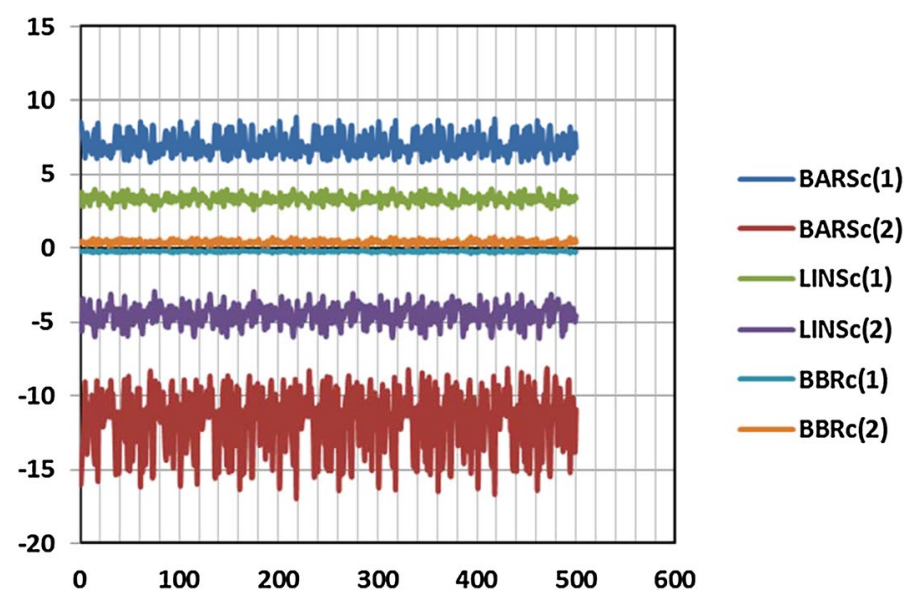

Fig. 1 Modification of the BARS, LINS, BBR estimators $c(1)$ and $c(2)$

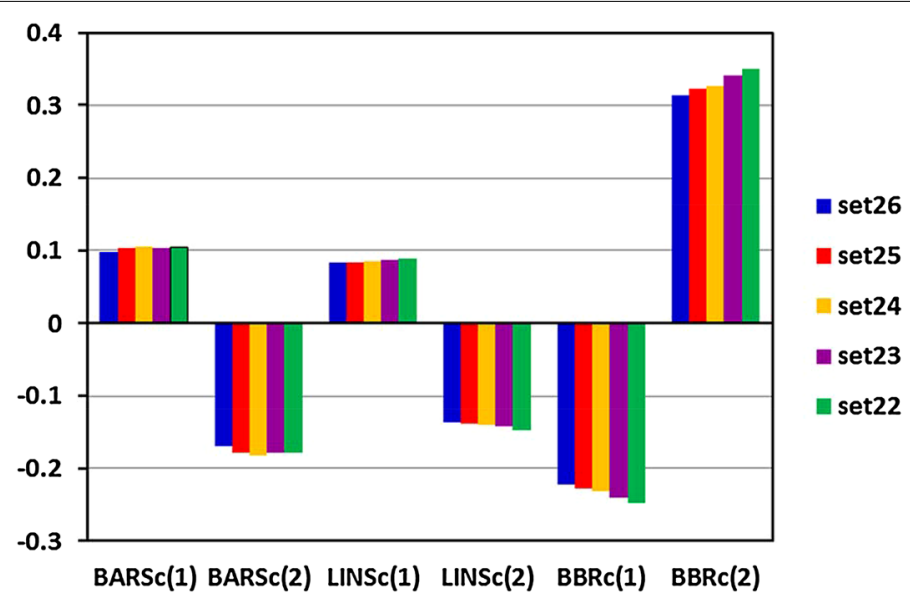

Fig. 2 Coefficient of variation for estimators

- the modification (from sample to sample) of separate estimators $c(1)$ and $c(2)$ and the ratios $\rho$;

- the stability degree of these indicators within each set of samples and overall; the coefficient of variation (CV in module) is used for such a purpose.

The modification of estimators $c(1)$ and $c(2)$ is plotted in Fig. 1. The samples are organized by sets as follows: Samples 1-100 are set26, samples 101-200 are set25; samples 201-300 are set24; samples 301-400 are set23; and samples 401-500 are set22.

All the estimators have the expected algebraic signs, and their change is significant, but occurs within a sufficiently stable band. The second feature is re-confirmed by the coefficients of variation computed distinctly for each set as in Fig. 2.

Regarding $c(1)$ therefore, the coefficients of variation oscillate around $8-10 \%$ for BARS and LINS curves, and between 22 and $25 \%$ for BBR one. The volatility is sensibly higher in the case of $c(2)$ in all these functions. 

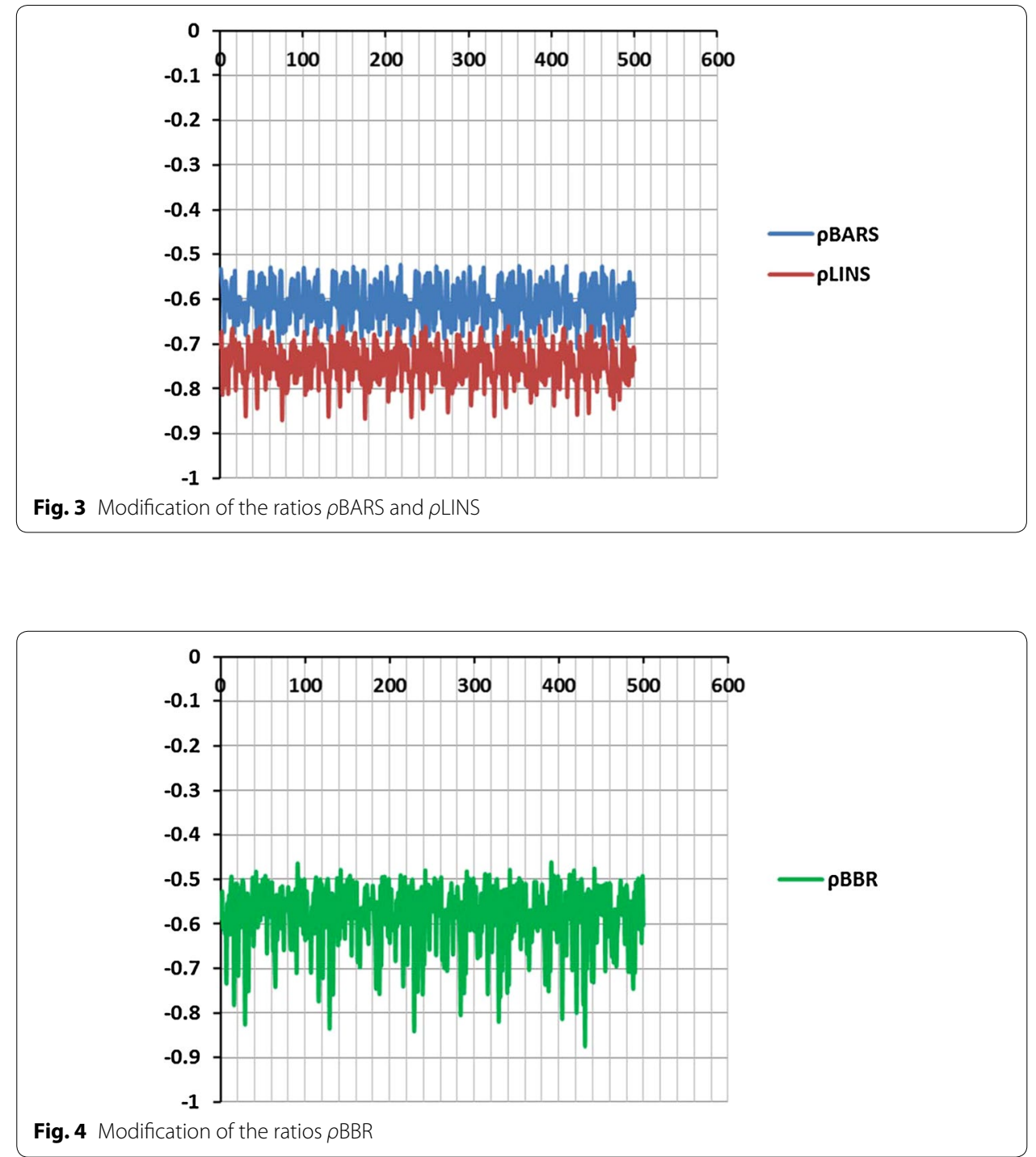

Despite its limited band, the modification of estimators, depending on the computational sample, is far from negligible. Under such circumstances, the examination of $\rho$ sensitivity is of particular importance. Figures 3 and 4 describe these ratios.

The $\rho$ ratios move; therefore, they are within considerably narrower bands. The coefficients of variation are conclusive (Fig. 5).

To notice that the volatility of $\rho$ ratios does not exceed the acceptable (from a practical viewpoint) borders and the sample sets differ very little among themselves.

The previous analysis has revealed the following:

- Estimators $c(1)$ and $c(2)$ register as really high coefficients of variation for all the curves, which can occur either from the available data or the adopted functional form of regression;

- by contrast, the ratios $\rho$ are characterized by sensibly lower such coefficients overall and within each sample's set. 


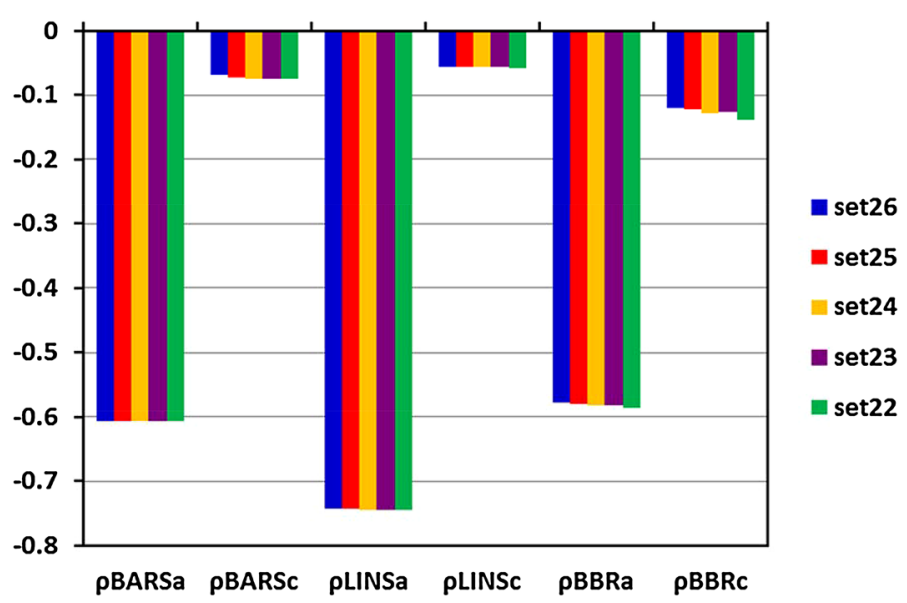

Fig. 5 Average (suffix a) and coefficient of variation (suffix $c$ ) of $\rho$ ratios

The last conclusion is essential. If the ratios $\rho$ are relatively stable, then the optimal points of the BARS, LINS, and BBR curves are again relatively stable for the samples (having of course, a similar informational structure as the primary series), or just these optimal points are of the greatest interest for macroeconomic analysis and simulations. In other words, the more stable the ratios $\rho$ are, so much the less would be justified to abandon the polynomial specification. Even if we did not intend, the "do nothing" option seems reasonable in our application. Some authors have already outlined that if the high VIFs are caused by the inclusion of powers or products of other variables, the multicollinearity could be ignored (Allison 2012).

In the case of the functional trinity of government finance, another computational problem is crucial. The real socioeconomic processes reflected by the BARS, LINS, and BBR curves are not isolated. By contrast, they are profoundly interconnected. The following chapter estimates them as a system of equations. The collinearity question will again be evoked.

\section{Results and discussion}

Econometric Eqs. (5), (7), (10), (13), (14), and (15) (supplemented by the corresponding accounting identities, some dummy variables, and the Ar terms) were integrated into a unitary model. This operation was accomplished in two steps.

First, these equations were solved as such, without any additional constraint. As a starting point, the iterative least squares were applied (Additional file 3: Appendix C-Sys2018OLS1). Since this method does not account for the possible interequation correlations, a seemingly unrelated regression (Additional file 3: Appendix C-Sys2018SUR1) was subsequently used.

The most significant results are concentrated in Table 2. The differences between the OLS and SUR estimations show that the impact of the interequation correlations cannot be ignored. Notably, the pair estimators $c(1)-c(2), c(5)-c(6)$, and $c(8)-c(9)$ have the expected algebraic signs in both procedures, which means that all the components of the BARS, LINS, and BBR functions display U-shaped slopes (an inverted form in the first two cases, and as such in the third one). 
Table 2 Estimations OLS1-SUR1

\begin{tabular}{|c|c|c|c|c|c|c|}
\hline \multirow[t]{2}{*}{ Estimator } & \multicolumn{3}{|c|}{ Iterative least squares } & \multicolumn{3}{|c|}{ Seemingly unrelated regression } \\
\hline & Coefficient & $t$ statistic & Prob. & Coefficient & $t$ statistic & Prob. \\
\hline$c(1)$ & 3.894841 & 3.581765 & 0.0005 & 3.344425 & 3.419789 & 0.0008 \\
\hline$c(2)$ & -6.11171 & -2.96783 & 0.0036 & -5.15028 & -2.78416 & 0.0062 \\
\hline$c(3)$ & 0.136385 & 2.260074 & 0.0255 & 0.14171 & 2.630572 & 0.0096 \\
\hline$c(4)$ & 0.294288 & 2.081649 & 0.0394 & 0.369918 & 2.904524 & 0.0044 \\
\hline$c(5)$ & 2.865476 & 11.7154 & 0 & 2.798618 & 12.87796 & 0 \\
\hline$c(6)$ & -3.30885 & -5.51001 & 0 & -3.1713 & -5.96151 & 0 \\
\hline$c(7)$ & -0.39527 & -2.25594 & 0.0258 & -0.372 & -2.43269 & 0.0164 \\
\hline$c(8)$ & -0.16799 & -4.3002 & 0 & -0.17296 & -6.09464 & 0 \\
\hline$c(9)$ & 0.266685 & 2.39636 & 0.018 & 0.283238 & 3.710497 & 0.0003 \\
\hline$c(10)$ & 0.073309 & 2.603768 & 0.0103 & 0.056011 & 2.779252 & 0.0063 \\
\hline$c(11)$ & 0.317634 & 3.663902 & 0.0004 & 0.360568 & 5.249144 & 0 \\
\hline$c(12)$ & 0.604139 & 5.234602 & 0 & 0.556234 & 6.127794 & 0 \\
\hline$c(13)$ & -0.51399 & -3.34185 & 0.0011 & -0.58888 & -4.78107 & 0 \\
\hline$c(14)$ & 1.557579 & 23.31209 & 0 & 1.571832 & 32.80355 & 0 \\
\hline$c(15)$ & -0.57783 & -8.59337 & 0 & -0.5922 & -12.3275 & 0 \\
\hline$c(16)$ & -0.46212 & -8.21488 & 0 & -0.46603 & -11.6207 & 0 \\
\hline$c(17)$ & 0.036793 & 4.726899 & 0 & 0.037518 & 6.377313 & 0 \\
\hline$c(18)$ & -0.86622 & -5.60487 & 0 & -0.88646 & -8.23769 & 0 \\
\hline$c(19)$ & 0.132421 & 3.88641 & 0.0002 & 0.118528 & 5.414735 & 0 \\
\hline
\end{tabular}

Although the BARS, LINS, and BBR relationships are gathered into a unique system, they are not explicitly interconnected. The second step of the present computational approach addresses this problem. The general equilibrium theory is useful in such a matter. If an integrated system has several optimizing entities, a structural compatibility is ultimately achieved among them. Why not consider the public finance blocks similarly? Since these blocks constitute a unitary system, rejecting the supposition that their dynamic trajectories are also interdependent would be difficult. More specifically, it would be implausible to assert that-for a given structural state-society relationshipthe dominant social preference concerning taxation would have no link to the dominant social choice for public expenditures.

This reasoning can be extended to budget balance, significantly influenced by the optimizing behavior of the potential lenders.

Returning to the examined system, from the optimal points of Eqs. (14a)-(14c), two significant equalities result:

$$
\begin{aligned}
& \text { oletg }=\text { oatax } *\left(c(5) * \text { oatax }+c(6) * \text { oata }^{2}\right) \\
& o c b b=c(8) *(c(8) /(-2 * c(9)))+c(9) *(c(8) /(-2 * c(9)))^{2}
\end{aligned}
$$

Based on (15a) and (15b), equilibrium formula (4) is added to the system in the following expression:

$$
\begin{aligned}
c(1) /(-2 * c(2))= & (c(5) /(-2 * c(6))) *\left(c(5) *(c(5) /(-2 * c(6)))+c(6) *(c(5) /(-2 * c(6)))^{2}\right) \\
& +\operatorname{cnfbr}(-1)-c(8) *(c(8) /(-2 * c(9)))+c(9) *(c(8) /(-2 * c(9)))^{2}
\end{aligned}
$$


Table 3 Estimations SUR2

\begin{tabular}{lccllccl}
\hline Estimator & Coefficient & $\boldsymbol{t}$ statistic & Prob. & Estimator & Coefficient & $\boldsymbol{t}$ statistic & Prob. \\
\hline$c(1)$ & 2.381749 & 3.837335 & 0.0002 & $c(11)$ & 0.362474 & 5.268048 & 0 \\
$c(2)$ & -3.12049 & -3.29485 & 0.0012 & $c(12)$ & 0.553518 & 6.1059 & 0 \\
$c(3)$ & 0.161709 & 3.167595 & 0.0019 & $c(13)$ & -0.59205 & -4.78954 & 0 \\
$c(4)$ & 0.442898 & 3.877219 & 0.0002 & $c(14)$ & 1.572393 & 33.14472 & 0 \\
$c(5)$ & 2.87114 & 13.78983 & 0 & $c(15)$ & -0.59283 & -12.469 & 0 \\
$c(6)$ & -3.35769 & -6.63002 & 0 & $c(16)$ & -0.4648 & -11.7486 & 0 \\
$c(7)$ & -0.33017 & -2.24893 & 0.026 & $c(17)$ & 0.037762 & 6.314574 & 0 \\
$c(8)$ & -0.16583 & -5.62014 & 0 & $c(18)$ & -0.88956 & -8.04251 & 0 \\
$c(9)$ & 0.26444 & 3.313027 & 0.0012 & $c(19)$ & 0.122241 & 5.380544 & 0 \\
$c(10)$ & 0.05932 & 2.829249 & 0.0053 & & & & \\
\hline
\end{tabular}

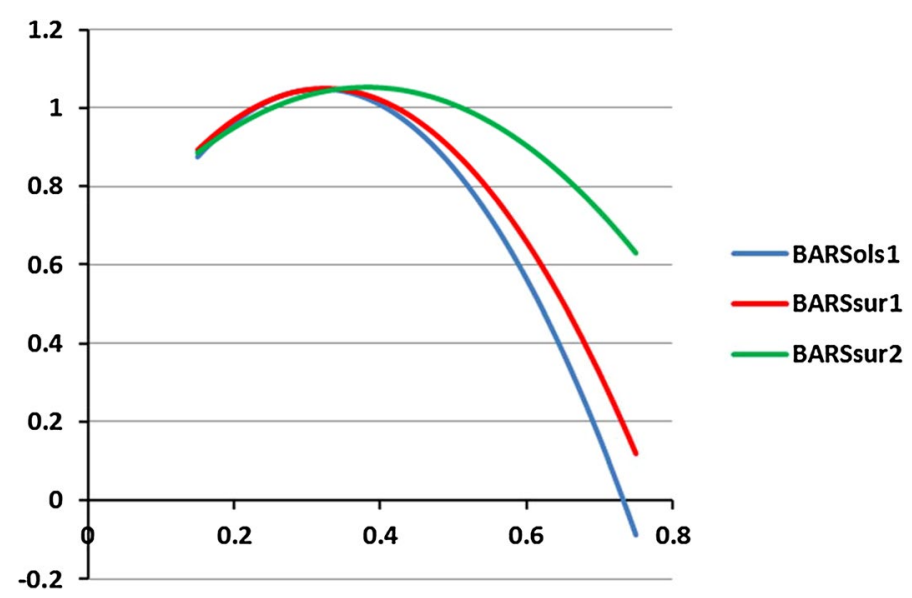

Fig. 6 Static BARS curve

This expression could be considered a "compatibility restriction" of the public budget model. Notably, (16) is not a simply computational artifice; by contrast, it comes from consistent socioeconomic reasons. Such a condition restrains the range of "estimating ambiguity" inducible by collinearity. Certainly, this solution requires further research, which would be justified not only for this discussed application but also for other economic problems approachable in a similar manner.

Re-computing our system under the compatibility restriction, the OLS method has failed to converge even after one million iterations (Additional file 3: Appendix C-Sys2018OLS2). Instead, the SUR technique (Additional file 3: Appendix C-Sys2018SUR2) has functioned and provided the estimations presented in Table 3.

In the static framework, the BARS, LINS, and BBR curves are calculated for a given temporal interval, changing their determinants within a large economically plausible range. The other explicative variables were fixed (maintained at the basic year level). The used estimators were provided by OLS1, SUR1, and SUR2.

The BARS curve, in the form $I G D P c=f(c b e)$, is approximated for the variation of $c b e(-1)$ from 0.15 to 0.65 , under the constancy of $\operatorname{IGFCFC}(-1)$, which is equal to 1.0626 , and time factor (=27) (Fig. 6). 


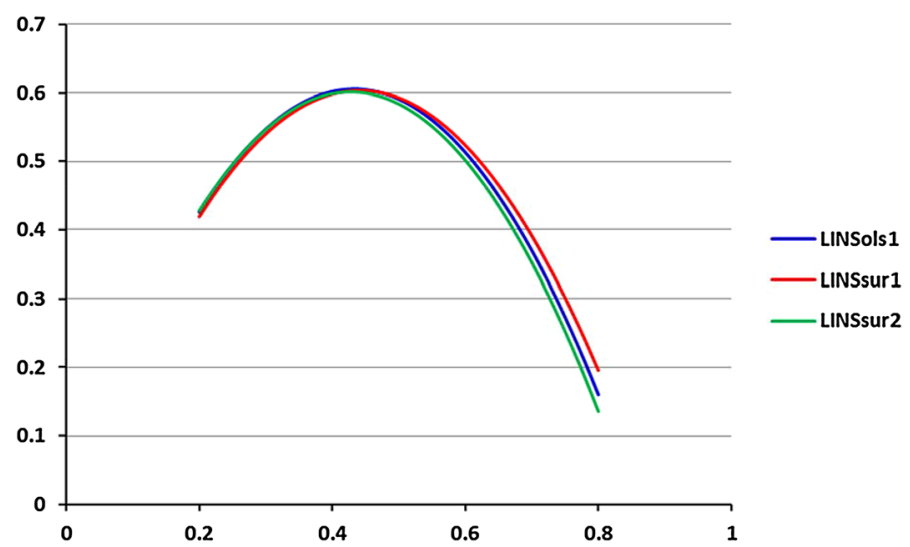

Fig. 7 Static LINS curve

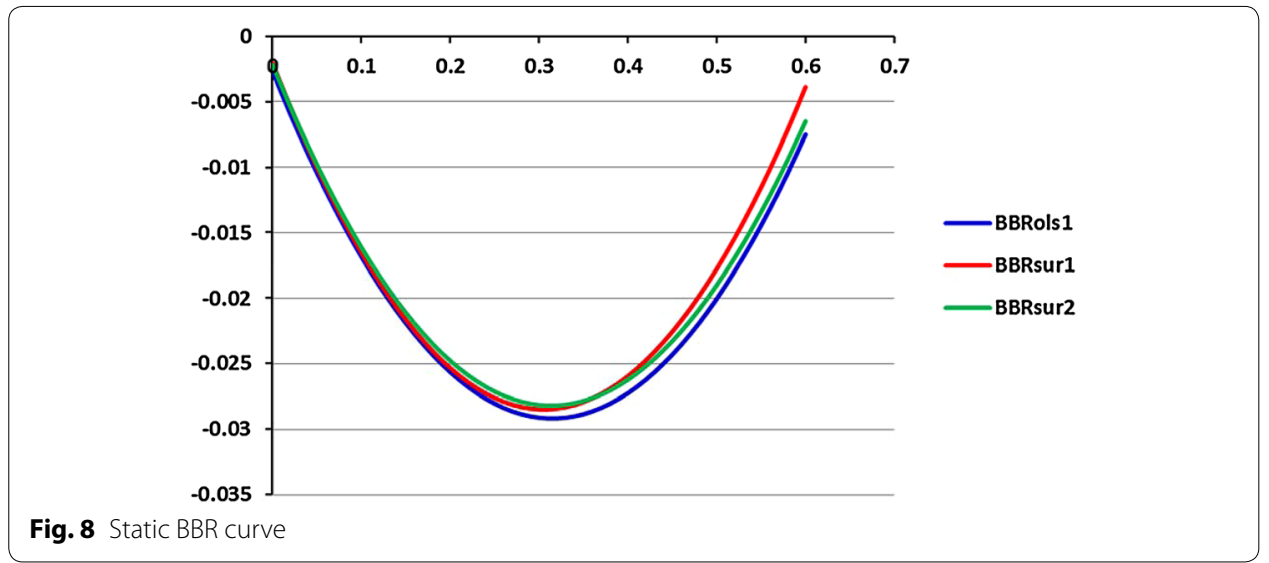

The modification of the IGDPc depends on the cbe configures; therefore, there is a clear inverted U-shaped BARS curve. Related to public spending and constancy of the investment influence, the economic growth reaches the maximum (1.053378) for $c b e=0.38$ in the proximity of ocbe $(=0.381631)$. Notably, such a level of $c b e$ is higher than the actual one $(0.338161$ in 2016).

The LINS curve, as letg $=f(\operatorname{atax})$, is calculated for a change of $\operatorname{atax}(-1)$ from 0.2 to 0.7, and the time factor is the same (=27) (Fig. 7).

Again, an inverted U-shaped curve is obtained, with the maximum $(=0.601526)$ for atax $=0.43$ (oatax $=0.427548)$, compared with 0.3869 in 2016.

The BBR function, in the form $c b b=f(p d g)$, is simulated for a variation of $p d g(-1)$ from zero (absence of the public debt) to 0.6. (the Maastricht Treaty ceiling). As in the previous exercises, the cyclical factor (sint4) is fixed (Fig. 8).

As expected, this time the simulations reveal a U-shaped curve. The maximal public budget deficit as ratio to the GDP $(-0.02819)$ is slightly lower than the Maastricht recommendation $(-0.03)$.

In conclusion, the static simulations confirm the presence of the BARS, LINS, and BBR curves in the statistical database. 
Undoubtedly, revealing how the model reacts as an integrated dynamic system to modifications in taxation and relative public debt would be of interest. Are the BARS, LINS, and BBR functions still valid under the intertemporal effect of the involved model factors? With this aim, the system was solved for ten post-sample successive intervals, and a horizon long enough to identify the dynamic properties of the model was observed. These intervals are labeled posts ${ }_{i}$, where $\mathrm{i}=0$ for the basic year, and $1 \ldots 10$ for the subsequent years. Simulations are operated using the estimators obtained from the SUR2 variant.

As a type of inertial scenario, the first application computes the system, starting with the database for 2016 as a basic year $(i=0)$. To avoid the impression of an authentic forecast, the subsequent intervals are noted as $1,2, \ldots, 10$.

The main hypothesis of the inertial scenario is the constancy of atax (at basic year level 0.3869), which signifies a fixed taxation system. The other indicators evolve strictly in concordance with the model estimators. Only the accounting relationship for $c b e$ is increased yearly by 0.035 , as an equivalent of the expected supplementary in-flows of non-reimbursable financial resources and, in particular, from the European Union structural funds. Computed under these premises, the resulting indicators are presented in Table 4.

The inertial scenario is useful as a referential or experimental subject for other applications; however, as such, it does not allow the identification of U-shaped trajectories appropriate for the main functional relationships of government finance. More suited for such a purpose are the simulations involving a significant modification of the main determinants of the model.

This is why the inertial scenario was solved for atax, determined by multiplying its basic level in all following ten intervals by a coefficient ranging between 0.7 and 1.5 (pace 0.025 , meaning 33 variants). The arithmetic mean of letg (noted mletg) for the entire generated in such a way series are displayed depending on the level of atax in Fig. 9.

The dynamic simulation re-confirms the LINS curve.

Increasing taxation induces a growth of government spending, respectively, of cbe. For each variant, there were computed average geometric indexes of the real GDP

Table 4 Inertial scenario

\begin{tabular}{llllllll}
\hline Interval & IGDPc & letg & $\boldsymbol{c b} \boldsymbol{b}$ & $\boldsymbol{c} \boldsymbol{b} \boldsymbol{e}$ & IGFCFc & $\boldsymbol{c n f b r}$ & $\boldsymbol{p d g}$ \\
\hline Basic & 1.047964 & 0.63233 & -0.02742 & 0.338161 & 1.0626 & 0.038667 & 0.413896 \\
posts1 & 1.048035 & 0.596436 & -0.02333 & 0.33113 & 1.146855 & 0.042033 & 0.437231 \\
posts2 & 1.060107 & 0.596842 & -0.01991 & 0.324878 & 1.124344 & 0.039052 & 0.457137 \\
posts3 & 1.054851 & 0.597222 & -0.02054 & 0.324569 & 1.109352 & 0.037958 & 0.477681 \\
posts4 & 1.052763 & 0.597577 & -0.02079 & 0.326235 & 1.070691 & 0.039244 & 0.498468 \\
posts5 & 1.047515 & 0.59791 & -0.01695 & 0.32532 & 1.057708 & 0.042033 & 0.515422 \\
posts6 & 1.045492 & 0.598222 & -0.01342 & 0.324528 & 1.069497 & 0.044652 & 0.528844 \\
posts7 & 1.04749 & 0.598517 & -0.01374 & 0.325935 & 1.074827 & 0.045628 & 0.542584 \\
posts8 & 1.049199 & 0.598794 & -0.01382 & 0.324997 & 1.057347 & 0.044502 & 0.556403 \\
posts9 & 1.046376 & 0.599056 & -0.0104 & 0.31921 & 1.050474 & 0.042033 & 0.566804 \\
posts10 & 1.043429 & 0.599304 & -0.00743 & 0.314002 & 1.063473 & 0.039697 & 0.574236 \\
\hline
\end{tabular}




\section{mletg}

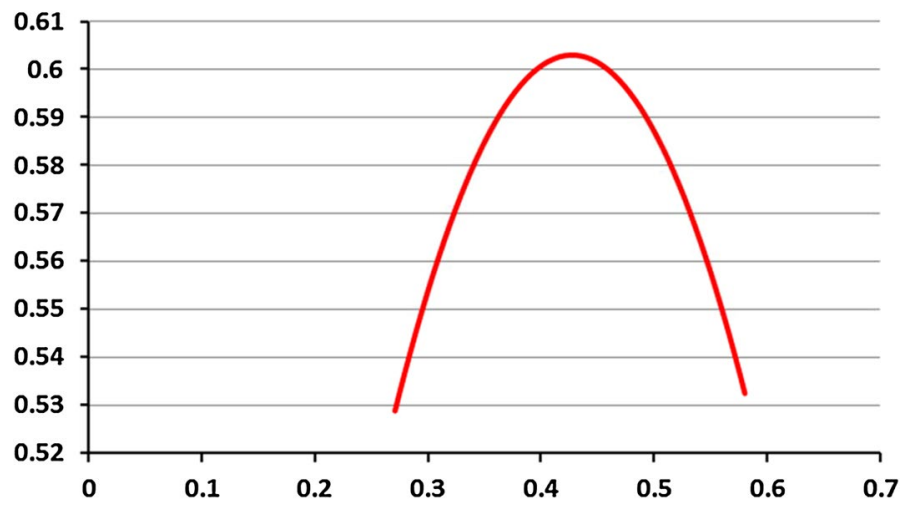

Fig. 9 Dynamic LINS curve

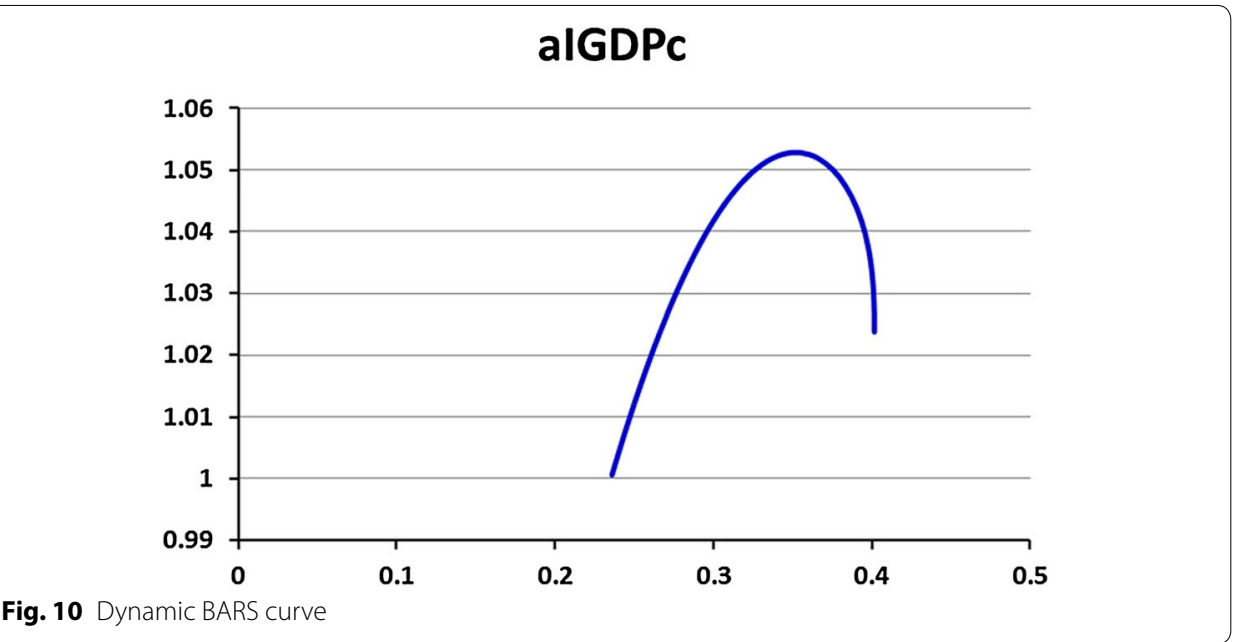

(noted $a I G D P c$ ), and the arithmetic mean of $c b e$ (noted $m c b e$ ) on the entire set of ten post-sample intervals. Figure 10 plots the variation of $a I G D P c$ depending on $m c b e$.

Consequently, the BARS curve is also present in the dynamic simulations.

To check the BBR curve, the simulations are operated on the level of the pdg in the basic interval as starting point of the series (noted $p d g 0$ ). The resulting indicator of interest in this case is the arithmetic mean of the ratio to GDP of the public budget balance (noted $m c b b$ ). Figure 11 describes its evolution.

The dynamic simulations also attest the BBR curve.

Obviously, the present exercises cannot be considered as practical recommendations, although such suggestions emerge. Our only goal was to illustrate the behavioral characteristics of the discussed model. Its operationalization would require transformations; among them, the explicit representation of the interconnections among the BARS, LINS, and BBR curves with other macroeconomic dependencies is essential. 


\section{mcbb}

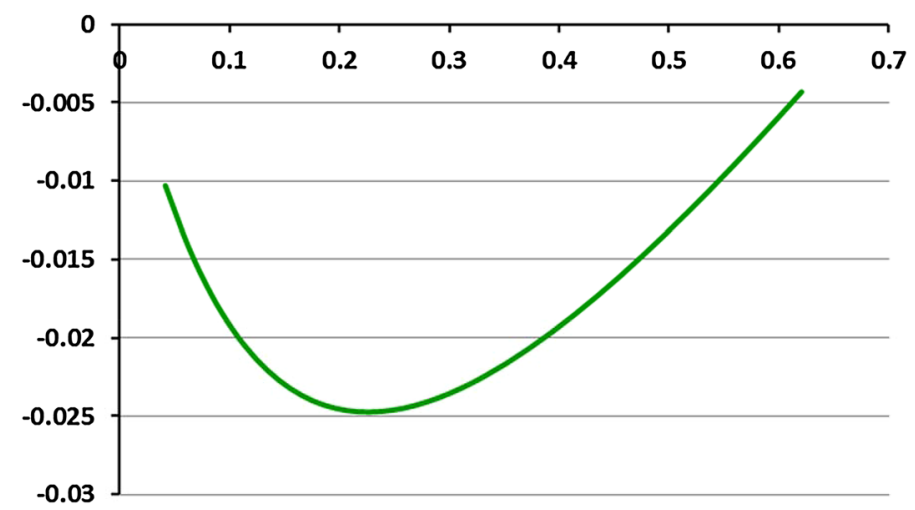

Fig. 11 Dynamic BBR curve

\section{Conclusions}

In line with the mainstream economic literature, this paper circumscribes government finances within the macrosocial triangle constituted by the following:

1. the impact of public expenditures on general human development and, in particular, economic growth;

2. the volume of taxes collected; and

3. the degree of government accessibility to borrowing additional resources when its spending exceeds the current public budget revenues.

The temporal scale of analysis is particularly important in an examination of this triangle. From this viewpoint, the paper distinguishes the following main perspectives:

1. the global historical trajectory of modern society, concerning which the WagnerKaldor theorem continues to have a leading explicative position;

2. the given structural state-society relationship as a component of the larger notion "given social context" or "given historical context"; and

3. the short-medium horizon, where the Keynesian and post-Keynesian framework remains relevant.

Each of these perspectives is characterized by specific requirements concerning the modeling work. Contradictory results provided in the empirical literature are explainable, at least partially, by the utilization of inadequate methodological instruments (theoretical hypotheses and functional specifications) on the available samples.

Our research focused on the second temporal scale, for which analysis-in mirror with the enounced functional triangle-the BARS, LINS, and BBR, curves were considered adequate. In addition to the literature that examined these relationships separately, this paper attempts to integrate them into a unitary system.

This paper assumes that under a given structural state-society relationship, the social propensity for government spending, tax acceptability, and risk aversion to 
public indebtedness move-more or less transparently-toward steady-state levels approximated by the optimal points of the BARS, LINS, and BBR as U-shaped (as such or inverted) curves.

In accordance with the general equilibrium paradigm, such points cannot be viewed separately because they are inherently interdependent. It seems natural to presume, for example, that the dominant social preferences concerning taxation are relatively concordant with the dominant social choices for public expenditures. Obviously, this reasoning can be extended to a balanced budget, which is significantly influenced by risk aversion to public indebtedness and optimizing behavior of potential lenders.

Consequently, the model specification was completed with an equation interlinking the optimal points of the BARS, LINS, and BBR functions, and this was admitted as a "compatibility restriction" of the system.

By using the database for an emergent medium-sized EU economy, the econometric analysis was finalized by model simulations in static and dynamic conditions. In static conditions, the resulting BARS, LINS, and BBR curves were determined for a given temporal interval, changing only their determinants of interest (with the other explicative variables remaining at their basic year level). In the second case, the entire system was solved for ten post-sample successive intervals, a horizon long enough to identify the dynamic properties (including the intertemporal effects) of all the involved indicators. Both types of simulations revealed the presence of the BARS, LINS, and BBR curves.

Certain crucial issues require, however, additional clarification. A deepened characterization of the given structural state-society relationship requires further multidisciplinary research from both the qualitative socioeconomic and quantitative statistical perspectives. A rigorous mathematical foundation of the "compatibility restriction" is also of great interest. Notably, the inclusion in the model of the possible variability of the optimal points of BARS, LINS, and BBR curves would be especially opportune under the present intensity of technological, demographic, and institutional changes.

\section{Additional file}

Additional file 1. Classification of the principal items and accounting relationships of the general consolidated budget of Romania (GCB).

Additional file 2. Data base.

Additional file 3. Equations systems.

\section{Abbreviations}

atax: average legal taxation; BARS: Barro-Armey-Rahn-Scully; $B B$ : public budget balance; $B B R$ : public budget balance restriction; $B E$ : volume of the public budget expenditures; $B R$ : volume of the public budget revenues; $c b b$ : ratio of $B B$ to GDP; cbbo: deviation of the effective $c b b$ from cbbr; cbbr: ceiling for $c b b$; cbe: ratio of $B E$ to GDP; IOT: contribution to IGB of non-budget factors; $c k$ : ratio of $P K$ to $P G D P$; $c$ fnfbr: the coefficient of the non-fiscal budget revenues; GCB: general consolidated budget; GDP: gross domestic product at current prices; GDPC: gross domestic product at constant prices; GFCF: gross fixed capital formation at current prices; GFCFC: gross fixed capital formation at constant prices; IGB: economic growth index; IGDPC: index of the GDP at constant prices; IGFCFC: index of the gross fixed capital formation at constant prices; letg: legal-effective taxation gap; LINS: Laffer in narrower sense; LOT: other factors (than atax) which influence the legt; NFBR: non-fiscal public budget revenues; oatax: optimal level of atax; OBB: other factors (than pdg) which influence the budget deficit within cbbr; ocbe: optimal level of cbe; opdg: optimal level of pdg; PD: public debt; $p d g$ : ratio of PD to GDP; PGDP: GDP deflator; $P K$ : fixed capital formation deflator; rgfcfc: ratio of the gross fixed capital formation to the gross domestic product at constant prices; $t$ : time factor; TAXT: total of the collected taxes; TAXTL: total of the legal taxation; Wb: part of the social welfare dependent on the GDP.

\section{Authors' contributions}

The author read and approved the final manuscript. 


\section{Acknowledgements}

The author thanks D. Jula, M. Matei, B. Păuna, C. Stănică for their help.

\section{Competing interests}

The author declares that he/she has no competing interests.

\section{Availability of data and materials}

Please see Additional files (Appendices) for data.

Funding

The author declares that there is not any funding for this research.

\section{Publisher's Note}

Springer Nature remains neutral with regard to jurisdictional claims in published maps and institutional affiliations.

Received: 25 April 2018 Accepted: 6 July 2018

Published online: 06 August 2018

\section{References}

Afonso A, Alves J (2016) Reconsidering Wagner's law: evidence from the functions of the government. Lisbon school of economics and management. Working papers no WP09/2016/DE/UECE. http://pascal.iseg.utl.pt/ depeco/wp/ wp092016.pdf. Accessed 29 Mar 2018

Afonso A, Schuknecht L, Tanzi V (2008) Income distribution determinants and public spending efficiency. European Central Bank. Working paper no 861. http://www.ecb.int/pub/pdf/scpwps/ecbwp861.pdf. Accessed 29 Mar 2018

Aghion P, Akcigit U, Cagé J, Kerr WR (2016) Taxation, corruption, and growth. National Bureau of Economic Research. NBER working paper no. 21928. http://www.nber.org/papers/w21928. Accessed 29 Mar 2018

Ahlborn M, Schweickert R (2016) Public debt and economic growth: economic systems matter. Center for European governance and economic development research. Discussion paper no. 281. https://www.econstor.eu/bitst ream/10419/129092/1/849499690.pdf. Accessed 29 Mar 2018

Akhand Z, Hubbard M (2016) Coercion, persuasion, and tax compliance: the case of large corporate taxpayers. Can Tax J 64:31-63

Allingham MG, Sandmo A (1972) Income tax evasion: a theoretical analysis. J Public Econ 1:323-338

Allison P (2012) When can you safely ignore multicollinearity? https://statisticalhorizons.com/multicollinearity. Accessed 29 Mar 2018

Alm J (2012) Measuring, explaining, and controlling tax evasion: lessons from theory, experiments, and field studies. Tulane economics working paper no. 1213. http://econ.tulane.edu/RePEc/pdf/tul1213.pdf. Accessed 29 Mar 2018

Altunc OF, Aydın C (2013) The Relationship between optimal size of government and economic growth: empirical evidence from Turkey, Romania and Bulgaria. Proc Soc Behav Sci 92:66-75

Andreoni J, Erard B, Feinstein J (1998) Tax compliance. J Econ Lit 36:818-860

Armey RK (1995) The freedom revolution: the new republican house majority leader tells why big government failed, why freedom works, and how we will rebuild America. Regnery Publishing, Washington

Asimakopoulos S, Karavias Y (2016) The impact of government size on economic growth: a threshold analysis. Econ Lett 139:65-68

Asimakopoulos S, Lorusso M, Pieroni L (2016) Can public spending boost private consumption? http://dx.doi. org/10.2139/ssrn.2849520, https://papers.ssrn.com/sol3/papers.cfm?abstract_id=2849520. Accessed 29 Mar 2018

Baguley T (2012) Serious stats: a guide to advanced statistics for the behavioral sciences. Palgrave Macmillan, London

Bania N, Gray JA, Stone JA (2007) Growth, taxes, and government expenditures: growth hills for US states. Natl Tax J 60:193-204

Barnett E, Casper M (2001) A definition of "social environment". Am J Public Health 91:465

Barro RJ (1990) Government spending in a simple model of endogeneous growth. J Polit Econ 98:S103-S125

Barro RJ (1991) Economic growth in a cross section of countries. Q J Econ 106:407-443

Bartlett B (2012a) The laffer curve, part 1. Tax notes 136. https://papers.ssrn.com/sol3/papers.cfm?abstract_id=2155974. Accessed 29 Mar 2018

Bartlett B (2012b) The Laffer curve, part 2. Tax notes 136. https://papers.ssrn.com/sol3/papers.cfm?abstract_id=2155978. Accessed 29 Mar 2018

Bartlett B (2012c) The Laffer curve, part 3. Tax notes 137, 74-76. https://papers.ssrn.com/sol3/papers.cfm?abstract_ id $=2155979$. Accessed 29 Mar 2018

Beach W (1998) Why taxes affect economic growth. Heritage lecture no. 624. http://www.heritage.org/research/lecture/ why-taxes-affect-economic-growth. Accessed 29 Mar 2018

Becsi Z (2000) The shifty Laffer curve. Econ Rev 85:53-64

Belsley DA (1991) Conditioning diagnostics: collinearity and weak data in regression. Wiley, New York

Bose N, Haque ME, Osborn DR (2003) Public expenditure and economic growth: a disaggregated analysis for developing countries. http://citeseerx.ist.psu.edu/viewdoc/download?doi=10.1.1.212.5175\&rep=rep1\&type=pdf. Accessed 29 Mar 2018

Bradley RA, Srivastava SS (1977) Correlation in polynomial regression. The Florida State University, Department of Statistics, Tallahassee, Florida. http://www.dtic.mil/dtic/tr/fulltext/u2/a039547.pdf. Accessed 29 Mar 2018

Brender A, Drazen A (2004) Political budget cycles in new versus established democracies. National Bureau of Economic Research. NBER working paper no. 10538. http://www.nber.org/papers/w10539.pdf. Accessed 29 Mar 2018 
Bruhin A, Fehr-Duda H, Epper T (2010) Risk and rationality: uncovering heterogeneity in probability distortion. Econometrica 78:1375-1412

Chamley C (1986) Optimal taxation of capital income in general equilibrium with infinite lives. Econometrica 54:607-622

Chao JCP, Grubel H (1998) Optimal levels of spending and taxation in Canada. In: Grubel HG (ed) How to use the fiscal surplus: what is the optimal size of government?. Fraser Institute, Vancouver, pp 53-68

Checherita-Westphal CD, Hallett AH, Rother PC (2012) Fiscal sustainability using growth-maximising debt targets. European Central Bank. Working paper no. 1472. https://www.ecb.europa.eu/pub/pdf/scpwps/ecbwp1472. pdf?eba46d7dae0f2347847a52b3011 eeea0. Accessed 29 Mar 2018

Chen GJ (2009) Staged regressions as a remedy to the multicollinearity problem. https://papers.ssrn.com/sol3/paper s.cfm?abstract_id=1339926. Accessed 29 Mar 2018

Chen GJ (2012) A simple way to deal with multicollinearity. J Appl Stat 39:1893-1909

Christie TAL (2011) Essays on Fiscal policy and economic growth. Dissertation, Georgia State University. https://schol arworks.gsu.edu/econ_diss/75. Accessed 29 Mar 2018

Churchill SA, Ugur M, Yew SL (2017) Does government size affect per-capita income growth? A hierarchical metaregression analysis. Econ Rec 93:142-171

Dalal DK, Zickar MJ (2012) Some common myths about centering predictor variables in moderated multiple regression and polynomial regression. Organ Res Methods 15:339-362

Dallal GE (2012a) Centering. http://www.jerrydallal.com/lhsp/center.htm. Accessed 29 Mar 2018

Dallal GE (2012b) Collinearity. http://www.jerrydallal.com/lhsp/collin.htm. Accessed 29 Mar 2018

DeLong JB, Summers LH (2012) Fiscal policy in a depressed economy, brookings papers on economic activity. https ://www.brookings.edu/wp-content/uploads/2012/03/2012a_delong.pdf. Accessed 29 Mar 2018

Devos K (2007) Measuring and analysing deterrence in taxpayer compliance research. J Aust Tax 10:182-219

Di Liddo G, Magazzino C, Porcelli F (2015) Decentralization, growth and optimal government size in the Italian regional framework. CREI Università Degli Studi Roma Tre. Working paper no. 0115. http://host.uniroma3.it/ centri/crei/pubblicazioni/workingpapers2015/CREI_01_2015.pdf. Accessed 29 Mar 2018

Dobrescu E (2013a) Macromodel of the Romanian economy (2012 version)-integrated system, contract with the national commission of prognosis, code SMIS 27153, technical report. National Commission for Prognosis

Dobrescu E (2013b) Updating the Romanian economic macromodel. Romanian J Econ Forecast 16:5-31

Dobrescu E (2015a) BARS curve in Romanian economy. Amfiteatru Econ 17:693-705

Dobrescu E (2015b) Net indirect taxes and the sectoral structure of economy. Romanian J Econ Forecast 18:5-29

Dobrescu E (2016a) Controversies over the size of the public budget. Romanian J Econ Forecast 19:5-34

Dobrescu E (2016b) LINS curve in Romanian economy. Amfiteatru Econ 18:136-152

Dormann CF, Elith J, Bacher S, Buchmann C, Carl G, Carré G, Marquéz JRG, Gruber B, Lafourcade B, Leitão PJ, Münkemüller T, McClean C, Osborne PE, Reineking B, Schröder B, Skidmore AK, Zurell D, Lautenbach S (2013) Collinearity: a review of methods to deal with it and a simulation study evaluating their performance. Ecography 36:27-46. https://doi.org/10.1111/j.1600-0587.2012.07348.x

Égert B (2015) The 90\% public debt threshold: the rise and fall of a stylized fact. Appl Econ 47:3756-3770

Elmendorf DW, Mankiw NG (2000) Government debt. National Bureau of Economic Research. NBER working paper no. 6470. https://papers.ssrn.com/sol3/papers.cfm?abstract_id=226215. Accessed 29 Mar 2018

Engen EM, Skinner J (1996) Taxation and economic growth. National Bureau of Economic Research. NBER working paper no. 5826. http://www.nber.org/papers/w5826.pdf. Accessed 29 Mar 2018

Facchini F, Melki M (2013) Efficient government size: France in the 20th century. Eur J Polit Econ 31:1-14

Farrar DE, Glauber RR (1967) Multicollinearity in regression analysis: the problem revisited. Rev Econ Stat 49:92-107

Feldstein M (1995a) Behavioral responses to tax rates: evidence from the tax reform act of 1986. Am Econ Rev 85:170-174

Feldstein M (1995b) The effect of marginal tax rates on taxable income: a panel study of the 1986 tax reform act. J Polit Econ 103:551-572

Feldstein M (1999) Tax avoidance and the deadweight loss of the income tax. Rev Econ Stat 81:674-680

Field J (2008) Social capital (key ideas). Routledge, New York

Fisman R, Gladstone K, Kuziemko I, Naidu S (2017) Do Americans want to tax capital? Evidence from online surveys. National Bureau of Economic Research. NBER working paper no. 23907. http://www.nber.org/papers/w2390 7.pdf. Accessed 29 Mar 2018

Florio M, Colautti S (2002) A logistic growth theory for government expenditures: a study of five countries over 100 years. Società Italiana di Economia Pubblica—Dipartimento di Economia Pubblica e Territoriale—Università di Pavia, pp 934-968. http://www.siepweb.it/siep/oldDoc/wp/162.pdf. Accessed 29 Mar 2018

Fölster S, Henrekson M (2001) Growth effects of government expenditure and taxation in rich countries. Eur Econ Rev 45:1501-1520

Gemmell N, Hasseldine J (2013) Taxpayers' behavioural responses and measures of tax compliance 'gaps': a critique. Victoria Business School. Working paper no. 11/2013. https://www.victoria.ac.nz/sacl/centres-and-institutes/ cpf/publications/pdfs/WP11_2013_Tax-Compliance-Gaps_26022014.pdf. Accessed 29 Mar 2018

Goldberger AS (1991) A course in econometrics. Harvard University Press, Cambridge

Gomez-Puig M, Sosvilla-Rivero S (2017) Public debt and economic growth: further evidence for the Euro area. ICEI working paper no. WP09/17. https://papers.ssrn.com/sol3/papers.cfm?abstract_id=3041117. Accessed 29 Mar 2018

Greene WH (2012) Econometric analysis. Pearson Education Limited, Harlowe

Greiner A (2014) Public debt and the dynamics of economic growth. Ann Econ Finance 15:185-204

Gujarati DN (2003) Basic econometrics. McGraw Hill, New York

Gwartney JD, Lawson R, Holcombe R (1998) The size and functions of government and economic growth. Prepared for the joint economic committee Jim Saxton, Chairman. http://frihetspartiet.net/function.pdf. Accessed 29 Mar 2018

Haan J (2014) Democracy, elections and government budget deficits. Ger Econ Rev 15:131-142 
Hajamini M, Falahi MA (2014) The nonlinear impact of government consumption expenditure on economic growth: evidence from low and low-middle income countries. Cogent Econ Finance 2:948122

Hansen BE (2018) Econometrics. https://www.ssc.wisc.edu/ bhansen/econometrics/Econometrics.pdf. Accessed 29 Mar 2018

Harberger AC (1964) Taxation, resource allocation and welfare. In: Role of direct and indirect taxes in the federal reserve system: a conference report of the NBER and the Brookings Institution. National Bureau of Economic Research Publications, Princeton University Press, Princeton, pp 25-80

Harberger AC (2003) Reflections on distributional considerations and the public finance, In Paper prepared for a course on practical issues of tax policy in developing countries, The World Bank, U.S. http://siteresources.worldbank.org/ INTTPA/Resources/HarbergerPaper.pdf. Accessed 29 Mar 2018

Hastie T, Tibshirani R, Friedman J (2008) The elements of statistical learning: data mining, inference, and prediction. Springer, New York

Helwig NE (2017) Regression with polynomials and interactions. http://users.stat.umn.edu/ helwig/notes/polyint-Notes .pdf. Accessed 29 Mar 2018

Hines JRJ (2002) Applied public finance meets general equilibrium: the research contributions of arnold harberger. http://www.bus.umich.edu/otpr/WP2002-1.pdf. Accessed 29 Mar 2018

Hoerl AE, Kennard RW (1970) Ridge regression: biased estimation for nonorthogonal problems. Technometrics 12:55-67 Holter HA, Krueger D, Stepanchuk S (2014) How does tax progressivity and household heterogeneity affect Laffer curves? Penn Institute for Economic Research, Department of Economics, University of Pennsylvania, PIER working paper no. 14-015. http://ssrn.com/abstract=2419154. Accessed 29 Mar 2018

Huang C (2006) Government expenditures in China and Taiwan: do they follow Wagner's law? J Econ Dev 31:139-148 lacobucci D, Schneider MJ, Popovich DL, Bakamitsos GA (2016) Mean centering helps alleviate "micro" but not "macro" multicollinearity. Behav Res Methods 48:1308-1317

Isakov K, Pekarski S (2015) Financial repression and Laffer curves. Higher school of economics research paper no. WP BRP 113/EC/2015. https://papers.ssrn.com/sol3/papers.cfm?abstract_id=2701807. Accessed 29 Mar 2018

Iyer GS, Reckers PMJ, Sanders DL (2010) Increasing tax compliance in Washington state: a field experiment. Natl Tax J 63:7-32

James S, Alley C (2002) Tax compliance, self-assessment and tax administration. J Finance Manag Public Serv 2:27-42 Johnson S, Kaufmann D, Shleifer A, Goldman MI, Weitzman ML (1997) The unofficial economy in transition. Brook Pap Econ Act 1997:159-239

Judd KL (1985) Redistributive taxation in a simple perfect foresight model. J Public Econ 28:59-83

Kahneman D, Tversky A (1979) Prospect theory: an analysis of decision under risk. Econometrica 47:263-291

Kaldor N (1962) The role of taxation in economic development, United Nations educational scientific and cultural organization, seminar on the programming of economic development. http://unesdoc.unesco.org/images/0015/00157 6/157615eb.pdf. Accessed 29 Mar 2018

Kaldor N (1963a) Taxation for economic development. J Mod Afr Stud 1:7-23

Kaldor N (1963b) Will underdeveloped countries learn to tax? Foreign Aff 41:410-419

Kenny LW, Winer SL (2006) Tax systems in the world: an empirical investigation into the importance of tax bases, administration costs, scale and political regime. Int Tax Public Finance 13:181-215

Kirchler E, Braithwaite V (2007) The economic psychology of tax behaviour. Cambridge University Press, Cambridge

Kleven HJ, Knudsen MB, Kreiner CT, Pedersen S, Saez EE (2010) Unwilling or unable to cheat? Evidence from a randomized tax audit experiment in Denmark. National Bureau of Economic Research. NBER working paper no. 15769. http://www.nber.org/papers/w15769. Accessed 29 Mar 2018

Klomp J, De Haan J (2013) Do political budget cycles really exist? Appl Econ 45:329-341

Kneller R, Bleaney MF, Gemmell N (1999) Fiscal policy and growth: evidence from OECD countries. J Public Econ 74:171-190

Kuckuck J (2012) Testing Wagners's law at different stages of economic development-a historical analysis of five western European countries. Institute of Empirical Economic Research, Osnabrueck University. Working paper no. 91. https://www.wiwi.uni-osnabrueck.de/fileadmin/documents/public/2_institute/2.02_IEW/IEW_Working_Paper/ WP_91.pdf. Accessed 29 Mar 2018

Kumar TK (1975) Multicollinearity in regression analysis. Rev Econ Stat 57:365-366

Kumar MS, Woo J (2010) Public debt and growth. IMF working paper no. WP/10/174. https://www.imf.org/external/pubs/ ft/wp/2010/wp10174.pdf. Accessed 29 Mar 2018

Laffer A (2004) The Laffer curve: past, present, and future, the heritage foundation. http://www.heritage.org/research/ reports/2004/06/the-laffer-curve-past-present-and-future. Accessed 29 Mar 2018

Laffer A (2012) The Laffer curve and the failure of stimulus spending. Lecture delivered to the institute of economic affairs 27th June 2012. IEA current controversies paper no. 38. https://ssrn.com/abstract=2182070 or http://dx.doi. org/10.2139/ssrn.2182070. Accessed 29 Mar 2018

Lee Y, Gordon RH (2005) Tax structure and economic growth. J Public Econ 89:1027-1043

Lof M, Malinen T (2013) Does sovereign debt weaken economic growth? A panel VAR analysis. https://mpra.ub.unimuenchen.de/52039/1/Debt_LM.pdf. Accessed 29 Mar 2018

Magableh MA (2006) A theoretical and empirical analysis of the Wagner hypothesis of public expenditure growth. PhD Thesis, School of Economics and Finance-University of Western Sydney, Sydney

Magazzino C (2012) Wagner's law and augmented Wagner's law in EU-27-A time-series analysis on stationarity, cointegration and causality. Int Res J Finance Econ 89:205-220

Magazzino C, Forte F (2010) Optimal size of government and economic growth in EU-27. Münich Personal RePEc archive. MPRA paper no. 26669. http://mpra.ub.uni-muenchen.de/26669/1/MPRA_paper_26669.pdf. Accessed 29 Mar 2018

Mahoney J (2000) Path dependence in historical sociology. Theory Soc 29:507-548

Mandel J (1985) The regression analysis of collinear data. J Res Natl Bur Stand 90:465-478 
Mark ST, McGuire TJ, Papke LE (1997) What do we know about the effect of taxes on economic development. Report prepared for the DC tax revision commission. http://www.dcwatch.com/taxrev/taxres15b.htm. Accessed 29 Mar 2018

Martinez-Vazquez J, Vulovic V, Liu Y (2011) Direct versus indirect taxation: trends, theory, and economic significance. In: Albi E, Martinez-Vazquez J (eds) The Elgar guide to tax systems. Edward Elgar, Cheltenham, pp 37-92

McBride W (2012) What is the evidence on taxes and growth? Tax foundation-center for state tax policy. Special report no. 207. https://files.taxfoundation.org/legacy/docs/sr207.pdf. Accessed 29 Mar 2018

Mendoza EG, Milesi-Ferretti GM, Asea P (1997) On the ineffectiveness of tax policy in altering long-run growth: Harberger's superneutrality conjecture. J Public Econ 66:99-126

Mertens K, Ravn MO (2013) The dynamic effects of personal and corporate income tax changes in the United States. Am Econ Rev 103:1212-1247

Mink M, de Haan J (2006) Are there political budget cycles in the Euro area? Eur Union Polit 7:191-211

Mukherjee D (2007) Reassembling the social environment: a network approach to human behavior. Adv Soc Work 8:208-218

Myles GD (2009) Economic growth and the role of taxation-theory. OECD Economics Department. Working papers no. 713. http://dx.doi.org/10.1787/222800633678, http://www.oecd-ilibrary.org/docserver/download/2228006336 78.pdf?expires=1520276233\&id=id\&accname=guest\&checksum=85820BCEOFAEBF174B11B54EC1A9ECAE. Accessed 29 Mar 2018

Myles GD (2014a) Behavioural explanations of individual tax compliance. TARC-Tax Administration Research Centre, Lecture 1 Center for Economic Studies. https://www.cesifo-group.de/de/dms/ifodoc/docs/neueseitences/CESLE CTURES/ces lectures2014-pdf/ces-myles-lect1.pdf. Accessed 29 Mar 2018

Myles GD (2014b) Experimental evidence on tax compliance. TARC — Tax Administration Research Centre, Lecture 2 Center for Economic Studies. https://www.cesifo-group.de/de/dms/ifodoc/docs/neueseitences/CESLECTURES/ ces_lectures2014-pdf/ces-myles-lect2.pdf. Accessed 29 Mar 2018

Nygård OE, Revesz JT (2015) Optimal indirect taxation and the uniformity debate: a review of theoretical results and empirical contributions. Statistics Norway—Research Department. Discussion papers no. 809. https://www.ssb. no/forskning/discussion-papers/_attachment/228490?_ts=14d70941718. Accessed 29 Mar 2018

O'Brien RM (2007) A caution regarding rules of thumb for variance inflation factors. Qual Quant 41:673-690

O'Hagan J, McCabe B (1975) Tests for the severity of multicolinearity in regression analysis: a comment. Rev Econ Stat 57:368-370

Panizza U, Presbitero AF (2012) Public debt and economic growth: is there a causal effect? MoFiR working paper no. 65. http://docs.dises.univpm.it/web/quaderni/pdfmofir/Mofir065.pdf. Accessed 29 Mar 2018

Panizza U, Presbitero AF (2013) Public debt and economic growth in advanced economies: a survey. Money-Finance Research Group. Working paper no. 78. http://docs.dises.univpm.it/web/quaderni/pdfmofir/Mofir078.pdf. Accessed 29 March 2018

Papava V (2002) On the Laffer effect in post-communist economies (on the bases of the observation of Russian literature). Probl Econ Transit 45:63-81

Pappadà F, Zylberberg Y (2016) Fiscal consolidation and tax compliance. Banque de France, international macroeconomics division. https://lagv-2016.sciencesconf.org/file/198820. Accessed 29 Mar 2018

Pattillo C, Poirson H, Ricci L (2002) External debt and growth. IMF working paper no. WP/02/69. https://www.imf.org/ external/pubs/ft/wp/2002/wp0269.pdf. Accessed 29 Mar 2018

Paul RK (2006) Multicollinearity: causes, effects and remedies. Indian Agricultural Statistics Research Institute (IASRI), New Delhi, India

Pescatori A, Sandri D, Simon J (2014) Debt and growth: is there a magic threshold? International Monetary Fund, Research Department. IMF working paper no. WP/14/34. http://papers.ssrn.com/sol3/papers.cfm?abstract_ id $=2407527 \&$ download=yes. Accessed 29 Mar 2018

Pettinger T (2017) Austerity-pros and cons. http://www.economicshelp.org/blog/5366/economics/austerity-pros-andcons/. Accessed 29 Mar 2018

Piegorsch WW (2015) Statistical data analytics foundations for data mining, informatics, and knowledge discovery. Wiley, New York

Piketty T, Saez E (2013) A theory of optimal inheritance taxation. Econometrica 81:1851-1886

Piolatto A, Rablen MD (2013) Prospect theory and tax evasion: a reconsideration of the Yitzhaki puzzle. Institute for Fiscal Studies. IFS working paper no. W13/25. http://www.ifs.org.uk/wps/wp201325.pdf. Accessed 29 Mar 2018

Poulson BW, Kaplan JG (2008) State income taxes and economic growth. Cato J 28:53

Rahn RW, Fox H (1996) What is the optimum size of government. Vernon K. Krieble Foundation, Denver

Reinhart CM, Rogoff KS (2010) Growth in a time of debt. National Bureau of Economic Research. NBER working paper no. 15639. http://www.nber.org/papers/w15639.pdf. Accessed 29 Mar 2018

Reinhart CM, Reinhart VR, Rogoff KS (2012) Public debt overhangs: advanced-economy episodes since 1800. J Econ Perspect 26:69-86

Robinson C, Schumacker RE (2009) Interaction effects: centering, variance inflation factor, and interpretation issues. Mult Linear Regres Viewp 35:6-11

Scully GW (1989) The size of the state, economic growth and the efficient utilization of national resources. Public Choice 63:149-164

Scully GW (1995) The "growth tax" in the United States. Public Choice 85:71-80

Scully GW (1998) Measuring the burden of high taxes. National Center for Policy Analysis. NCPA policy report no. 215. https://www.heartland.org/_template-assets/documents/publications/5227.pdf. Accessed 29 Mar 2018

Seber GAF, Lee AJ (2003) Linear regression analysis. Wiley, New York

Shacham M, Brauner N (1997) Minimizing the effects of collinearity in polynomial regression. Ind Eng Chem Res 36:4405-4412

Shi M, Svensson J (2006) Political budget cycles: do they differ across countries and why? J Public Econ 90:1367-1389

Slemrod J, Yitzhaki S (2002) Tax avoidance, evasion, and administration. In: Auerbach AJ, Feldstein M (eds) Handbook of public economics. Elsevier Science, New York, pp 1425-1470 
Soldatos GT (2015) Tax aversion, Laffer curve, and the self-financing of tax cuts. Appl Econ Finance 2:14-18

Stone J (2014) Do balanced-budget rules increase growth? MPRA paper 57605. https://mpra.ub.uni-muenchen.de/57605 /13/MPRA_paper_57605.pdf. Accessed 29 Mar 2018

Tanzi V (2005) The economic role of the state in the 21st century. Cato J 25:617-638

Tanzi V, Schuknecht L (1996) Reforming government in industrial countries. Finance and Development, September, 2-5. http://www.imf.org/external/pubs/ft/fandd/1996/09/pdf/tanzi.pdf. Accessed 29 Mar 2018

Tanzi V, Schuknecht L (2000) Public spending in the 20th century—a global perspective. Cambridge University Press, Cambridge

Torgler B, Schaltegger CA (2006) Tax morale: a survey with a special focus on Switzerland. Swiss J Econ Stat 142:395-425

Trecroci C, Salotti S (2014) The impact of government debt, expenditure and taxes on aggregate investment and productivity growth. https://papers.ssrn.com/sol3/papers.cfm?abstract_id=2033107 or http://dx.doi.org/10.2139/ ssrn.2033107. Accessed 29 Mar 2018

Uriel E (2013) Relaxing the assumptions in the linear classical model. http://www.uv.es/uriel/6\%20Relaxing\%20assumpti ons\%20in\%20the\%20linear\%20classical\%20model.pdf. Accessed 29 Mar 2018

van Wieringen W (2018) Department of epidemiology and biostatistics VUmc \& Department of Mathematics, VU University Amsterdam, The Netherlands. http://www.few.vu.nl/ wvanwie/Courses/HighdimensionalDataAnalysis/ WNvanWieringen_HDDA_Lecture23_RidgeRegression_20172018.pdf. Accessed 29 Mar 2018

Wagner A (1883) Three extracts on public finance. In: Musgrave RA, Peacock AT (eds) Classics in the theory of public finance. MacMillan, London, pp 1-15

Walewski M (2009) A short play on the idea of the laffer curve in transition economies. CASE network studies and analyses no. 175. https://papers.ssrn.com/sol3/papers.cfm?abstract_id=1444807. Accessed 29 Mar 2018

Wasylenko M (1997) Taxation and economic development: the state of the economic literature. N Engl Econ Rev 37-52. https://surface.syr.edu/cgi/viewcontent.cgi?article=1001\&context=ecn. Accessed 29 Mar 2018

Wichers CR (1975) The detection of multicollinearity: a comment. Rev Econ Stat 57:366-368

Winer SL (2016) The political economy of taxation: power, structure, redistribution. In: Congleton R, Grofman B, Voigt S (eds) Forthcoming in the Oxford handbook of public choice. Carleton University, Ottawa, pp 1-40

Wold S, Ruhe A, Wold H, Dunn IW (1984) The collinearity problem in linear regression. The partial least squares (PLS) approach to generalized inverses. SIAM J Sci Comput 5:735-743

Wooldridge JM (2009) Introductory econometrics: a modern approach. South-Western-Cengage Learning, Mason

Xing J (2011) Does tax structure affect economic growth? Empirical evidence from OECD countries. Oxford University Centre for Business Taxation. Working paper no. WP11/20. http://eureka.bodleian.ox.ac.uk/3213/1/WP1120.pdf. Accessed 29 Mar 2018

Yitzhaki S (1974) A note on income tax evasion: a theoretical analysis. J Public Econ 3:201-202

Younker J (2012) Ridge estimation and its modifications for linear regression with deterministic or stochastic predictors. Master's Thesis. University of Ottawa, Ottawa. https://ruor.uottawa.ca/bitstream/10393/22662/5/Younker_James _2012_Thesis.pdf. Accessed 29 Mar 2018

Yu CH, Tempe AZ (2000) An overview of remedial tools for collinearity in SAS. https://www.lexjansen.com/wuss/2000/ WUSS00040.pdf. Accessed 29 Mar 2018

\section{Submit your manuscript to a SpringerOpen ${ }^{\circ}$ journal and benefit from:}

Convenient online submission

- Rigorous peer review

- Open access: articles freely available online

- High visibility within the field

- Retaining the copyright to your article

Submit your next manuscript at $\boldsymbol{\Delta}$ springeropen.com 